\title{
Brain activity during walking in older adults: Implications for compensatory versus dysfunctional accounts.
}

T. Fettrow ${ }^{1}$, K. E. Hupfeld ${ }^{1}$, G. Tays ${ }^{1}$, D. J. Clark ${ }^{2,3}$, Patricia A. Reuter-Lorenz ${ }^{5}$ \& R. D. Seidler $r^{1,4^{*}}$

1Department of Applied Physiology and Kinesiology, University of Florida, Gainesville, FL ${ }^{2}$ Department of Aging and Geriatric Research, University of Florida, Gainesville, FL

${ }^{3}$ Brain Rehabilitation Research Center, Malcom Randall VA Medical Center, Gainesville, FL

${ }^{4}$ Norman Fixel Institute for Neurological Diseases, University of Florida, Gainesville, FL

${ }^{5}$ Department of Psychology, University of Michigan, Ann Arbor, MI

${ }^{*}$ Correspondence to:

Tyler Fettrow

tfettrow@ufl.edu

\section{Highlights}

- We provide an overview of two prevalent conceptual accounts of brain aging.

- We review locomotion studies in older adults that quantify brain function and evaluate fit with these accounts.

- Findings from many of these mobility studies support the idea that brain activity may reflect either compensation during activities of low difficulty, and are more likely to support neural dysfunction as the task difficulty increases.

- To elucidate the neural control of mobility in older adults, we suggest that future experiments systematically vary task difficulty levels to clarify whether brain activity during locomotion reflects compensatory versus dysfunctional processes. 


\section{Abstract (limit 170)}

A prominent trend in the functional brain imaging literature is that older adults exhibit increased brain activity compared to young adults to perform a given task. This phenomenon has been extensively studied for cognitive tasks, with the field converging on interpretations described in two alternative accounts. One account interprets over-activation in older adults as reflecting neural dysfunction, whereas another interprets it as neural compensation. Here we review studies that have recorded brain activity and walking measurements in older adults, and we categorize their findings as reflecting either neural dysfunction or neural compensation. Based on this synthesis, we recommend including multiple task difficulty levels in future work to help differentiate if and when compensation fails as the locomotion task becomes more difficult. Using multiple task difficulty levels with neuroimaging will lead to a more advanced understanding of how age-related changes in locomotor brain activity fit with existing accounts of brain aging and support the development of targeted neural rehabilitation techniques.

Keywords: brain activity, walking, aging, compensation, dysfunction, neural control

\section{Introduction}

Walking and balance function are major concerns for the aging population. This is a costly problem, with fall related injuries amounting to $\$ 50$ billion in the U.S in 2015 alone (Florence et al., 2018). Identifying the neural processes that contribute to functional mobility declines with advancing age could lead to new interventions that slow such declines.

Brain functional activity changes with age. Many experiments have revealed that older adults generally recruit additional brain regions compared to young adults when performing a given task (Calautti et al., 2001; V. S. Mattay et al., 2002; Ward \& Frackowiak, 2013). In addition, older adults tend to exhibit less activity in task-relevant brain areas as well (Grady, 2012; Marx et al., 2003; Noohi et al., 2019). Interpretations regarding these age differences are still debated.

The cognitive literature has suggested (at least) two primary interpretations of over-activation in older adults: neural dysfunction and neural compensation. Figure 1 depicts hypothetical behavioral performance and brain activity for both young and older adults. Brain-behavior associations allow us to differentiate the older adults who exhibit compensatory brain over-activation (light blue) versus neural dysfunction (dark blue). That is, over-activation is interpreted as compensatory if it is associated with better performance, or dysfunctional if it is associated with poorer performance. We expect older individuals who exhibit neural compensation (Old Compensatory group in Figure 1) to perform relatively well compared to their age-matched peers, but with increased brain activity (relative to young adults) supporting this performance advantage. Alternatively, we would consider brain activity that is not accompanied by preserved performance as reflecting neural dysfunction (dark blue). Furthermore, compensatory over-activation that contributes positively to task performance, may reach a neural resource ceiling, either by increasing activation amplitude in task-appropriate brain regions or by recruiting additional brain regions (Reuter-Lorenz \& Cappell, 2008). Such compensation may help—at least in the short term - to overcome age-related brain structural, blood flow, and / or biochemical declines, or even dysfunctional brain activity (Heuninckx et al., 2008; Madden et al., 1999; V. S. Mattay et al., 2002; Reuter-Lorenz et al., 2000). 


\section{Brain-Behavior Relationship}

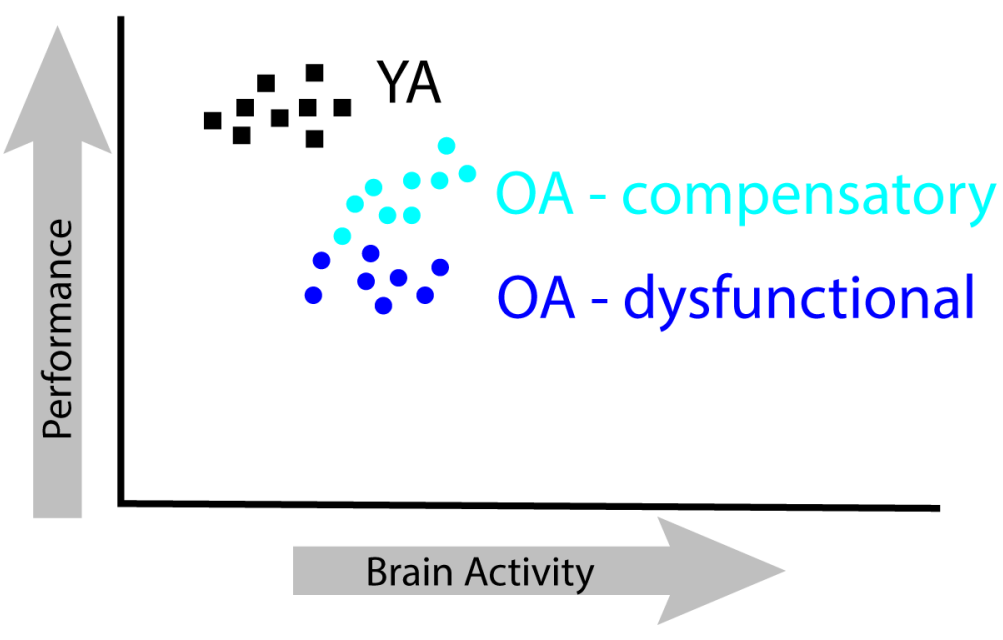

Figure 1: Illustration of the hypothetical relationship between behavioral performance and brain activity. Young adults show lower brain activity with higher performance relative to older adults. The old neural compensation group (light blue) shows higher performance than the old dysfunctional group, despite similar levels of brain activity. Moreover, greater brain activity within this group is associated with better performance. This indicates the brain activity in the old compensatory group is beneficial for preserving performance. Performance measures are the basis for categorizing agerelated brain over-activation as

compensatory or dysfunctional.

Dysfunctional over-activation in older adults may result from a number of underlying factors (Koen \& Rugg, 2019), including a reduction in specificity of neural representations (Baltes \& Lindenberger, 1997; Li \& Lindenberger, 2002). Evidence suggests that the functional specialization that characterizes the young adult brain breaks down with aging - this is referred to as dedifferentiation. The ability of a brain area to support its intended task (e.g., the visual cortex processing visual information) generally reduces with age, and regions may become involved for other tasks. Lindenberger \& Baltes $(1994,1997)$ identified that sensory and cognitive performance are more strongly associated with each other in older than young adults, suggesting more shared processing resources, or less specificity of neural processes as age increases. Diffuse biochemical changes may be contributing to global breakdown of neural networks. A computational model of a neural system with reduced dopaminergic modulation reproduced the expected neural noise that accompanies more diffuse brain connectivity (Li et al., 2001; S.C. Li \& Lindenberger, 1999). Single-neuron recordings have shown that the visual orientation tuning curve is less selective in older macaque monkeys compared to younger monkeys (Schmolesky et al., 2000). Further, the visual orientation tuning curve has been improved with administration of Gamma Aminobutyric Acid (GABA) agonists (Eysel et al., 1998; Sato et al., 1996), suggesting loss of GABA neurotransmitters contributes to the observed changes in old age (Dustman et al., 1996). Recent research suggests that less segregation of sensorimotor brain networks (Cassady et al., 2019; King et al., 2018) and reduced specificity of motor neural representations (Bernard \& Seidler, 2012; Carp et al., 2011) relates to poorer sensorimotor performance among older adults (Bernard \& Seidler, 2012; Carp et al., 2011; Cassady et al., 2019; Hausman et al., 2019). Thus, neural dysfunction may contribute to mobility declines with age. The underlying cause of neural dysfunction remains speculative, but possible contributing factors include systemic axon degeneration, loss of synapses, and reduction of neurotransmitter availability and function with advancing age (Cassady et al., 2019; Seidler et al., 2010).

The compensation hypothesis suggests that, for a particular level of task demand, additional neural resources are recruited to overcome neural deficits and preserve task performance (ReuterLorenz et al., 1999). As age-related declines progress, additional brain resources may be recruited to meet the demands of successful task performance. In cognitive tasks, older adults who exhibit 
increased activation tend to perform better than those who do not (Reuter-Lorenz et al., 2000). Recent work suggests a relationship between decreasing white matter integrity and increasing functional activation, as if to compensate for the white matter decline, coined the "less wiring more firing" principle (Daselaar et al., 2015; Davis et al., 2012). Since the 1990s, compensation has been used to describe the age-related adaptations that retain function (Bäckman \& Dixon, Roger, 1992; Cabeza et al., 1997; Grady et al., 1994, 2000). Often during difficult tasks, compensatory overactivation is observed in prefrontal brain areas and in the contralateral, homologous brain region to that recruited by young adults performing the same task (Cabeza et al., 2004; Reuter-Lorenz et al., 2000). It should be noted that compensation and dysfunction are not mutually exclusive frameworks, as compensation may occur to counteract dysfunction. Furthermore, dysfunctional patterns may emerge as compensatory resource ceilings are reached (Reuter-Lorenz \& Cappell, 2008).

In the present review, we synthesize the literature reporting age differences in brain activity and walking performance. In this nascent field, few studies to date have interpreted brain-behavior relationships in the context of existing brain aging accounts. We summarize the research from the past couple of decades where the methodologies and analyses permit such interpretation. We include articles that quantified brain activity during walking tasks with mobile imaging techniques including functional Near Infrared Spectroscopy (fNIRS) and electroencephalography (EEG), as well as imagined walking performed in the MRI or Positron Emission Tomography (PET) environment as a proxy for physical walking (Jahn et al., 2004, 2008; la Fougère et al., 2010). Of note, many of the included experiments were not designed to explicitly evaluate brain aging theories, although their study design permits such interpretation. We close with suggestions for design and implementation of future studies to facilitate interpretation with respect to compensatory versus dysfunctional accounts.

\section{Methodological Considerations}

We identified articles that (a) recorded functional brain activity during either walking or imagined walking and (b) related brain activity to walking performance. We categorized the articles into those that employed Single-Task Assessments (standard walking) and those that employed Task Difficulty Manipulations (multiple difficulty levels). The experiments within the Task Difficulty Manipulation category are subdivided into manipulations of the task of walking itself (Terrain Modifications) and manipulations of the cognitive resources available during the walking task (Divided Attention). This approach to categorization is explained in more detail below.

\subsection{Single-Task Assessments}

As illustrated in Figure 1, brain activity patterns can be linked to the compensation versus dysfunction hypotheses in studies that employ only a single task and assess brain-behavior relationships between old and young adults, or among subgroups of good and poor performing older adults. A single-task assessment can be obtained using mobile brain imaging during walking or stationary brain imaging (e.g., MRI) during imagined walking. Functional MRI has high spatial resolution, but requires participants to lie supine and motionless. Most MRI assessments of mobility have used imagined walking tasks or compared MRI-measured brain activity to walking performance on a separate occasion (e.g., fMRI activity during a cognitive task compared to walking outside of the scanner). We review articles that report using either of these methodologies.

\section{$\underline{\text { 2.2 Task Difficulty Manipulations }}$}


The use of multiple task difficulty levels (e.g., modifying the walking terrain or adding a secondary attention distracting task) can provide insight into potential limits of compensatory processes. Specifically, variations in difficulty can help to determine the point at which evidence of neural dysfunction emerges and a task becomes sufficiently challenging that compensatory reserves are exceeded, or indicate persistent dysfunction across all difficulty levels (Reuter-Lorenz \& Cappell, 2008). Past work supports that increasing task difficulty results in increased brain activity within the brain regions recruited by healthy young adults. For instance, this finding has been demonstrated in several studies in various cognitive domains (Cappell et al., 2010; C. Grady, 2012; Heinzel et al., 2014; Venkata. S. Mattay et al., 2006; Reuter-Lorenz et al., 2000; Schneider-Garces et al., 2010), with older adults exhibiting proportionally higher activation increases as the load increased compared to young adults (Godde \& Voelcker-Rehage, 2010; Hamacher et al., 2015; Meunier et al., 2014). Typically, as a task becomes more difficult, performance will decline. In the next two sections, we describe common methods for increasing the difficulty of walking.

\section{$\underline{\text { 2.2.1 Terrain Modifications }}$}

Walking terrain impacts mobility (Shumway-Cook et al., 2002). In the lab, terrain can be manipulated by having participants walk on a flat surface and over obstacles (Schulz, 2012). Obstacle navigation is more difficult because the leading foot must be adjusted on approach and landing to avoid tripping or stepping on an obstacle, and foot clearance of both leading and trailing feet must be adjusted during obstacle crossing steps. Furthermore, the gait cycle becomes asymmetrical during obstacle crossing. Using tasks such as obstacle negotiation to increase walking difficulty allows for characterization of how brain activity changes in response to task demands. Therefore, in this review, we included studies that used mobile brain imaging to compare brain activity during normal walking versus tasks with more difficult motor demands such as the presence of obstacles. We refer to these articles as those implementing Terrain Modifications.

\subsubsection{Divided Attention Modifications}

Researchers commonly use a secondary task unrelated to walking (e.g., counting backwards by sevens) to increase the difficulty of the locomotion task. A growing body of evidence shows that dualtask costs, defined as the reduction in performance when executing two tasks at the same time, are typically larger in older than young adults (Li et al., 2018; Lövdén et al., 2008). This evidence suggests that older adults allocate more attention to the control of walking than young adults, and older adults place greater priority on walking than on the cognitive task (Brown et al., 2002). Many studies investigating walking with dual-task paradigms use verbal fluency (e.g., reciting alternate letters of the alphabet) or serial subtraction (e.g., counting backwards by threes or sevens) tasks with walking. Dual tasking does not modify the difficulty of walking per se, but rather creates competition for a limited set of resources. We refer to these articles as those implementing Divided Attention Modifications.

\section{Literature Search}

We searched PubMed with specific criteria. Articles were considered eligible for inclusion if the title and abstract included the search terms listed in Table 1. Articles were excluded prior to the year 2000 because to our knowledge, there are no known relevant studies prior to this date. Other inclusion / exclusion criteria are provided in Table 2. The search yielded 217 articles. Three authors (TF, KH, 
GT) performed the initial screening using the inclusion and exclusion criteria in Table 2. We excluded 149 articles based on information contained within the abstracts. We screened the remaining 68 articles in detail to determine their relevance and our potential to interpret the findings using the theories of brain aging. We excluded 41 articles based on lack of group comparisons (i.e., young versus older adults) or, if the article only included older adults and no difficulty level modulation. Seven papers were included in the Single-Task Assessment category and 20 were in the TaskDifficulty Manipulation category. Within the Task-Difficulty Manipulation category we identified 12 and 8 papers matching the categories of Terrain Modifications and Divided Attention Modifications ( 3 overlapping between the two), respectively. All articles included in this review are cited in Tables 4, 5, and 6 and bolded in the text for easy identification.

\section{Search Terms}

Population: "old age" OR "older" OR "elderly" OR "aging"

AND

Brain Activity: "fnirs" OR "functional near-infrared spectroscopy" OR "eeg" OR

"electroencephalogram" OR "fmri" OR "functional magnetic resonance imaging" OR "pet" OR "positron emission tomography" OR "brain activity" OR "neural activity"

\section{AND}

Behavior: "balance" OR "walking" OR "gait" OR "mobility" OR "locomotion" OR "imagined walking" AND

Year: "2000/01/01"

Table 1: Search terms used for identifying the experiments that acquired brain activity during or in relation to mobility related tasks.

\section{Inclusion and Exclusion Criteria}

Inclusion

- Studies that compared older and young adults' brain activity and walking performance.

- Studies that measured older adults' brain activity and walking during multiple difficulty levels.

- Studies that used some form of mobile brain imaging while participants were walking, turning, obstacle crossing, walking while performing another task (dual-task), etc.

- Studies that measured brain activity during imagined walking and related it to a walking or mobility measure acquired outside of the scanner.

- Studies that measured brain activity during a stationary acquisition (PET or $\mathrm{MRI}$ ) and related it to a walking or mobility measure acquired outside of the scanner.
Exclusion

- Studies that were not written in English

- Studies that did not present data from healthy older adults.

- Studies that present measures of brain structure rather than function.

- Studies where the older adult group were also patient populations (PD, MS, diabetes, obesity)

- Studies that explored an intervention.

Table 2: Inclusion and exclusion criteria applied to systematic search. 


\section{Records Flow Chart}

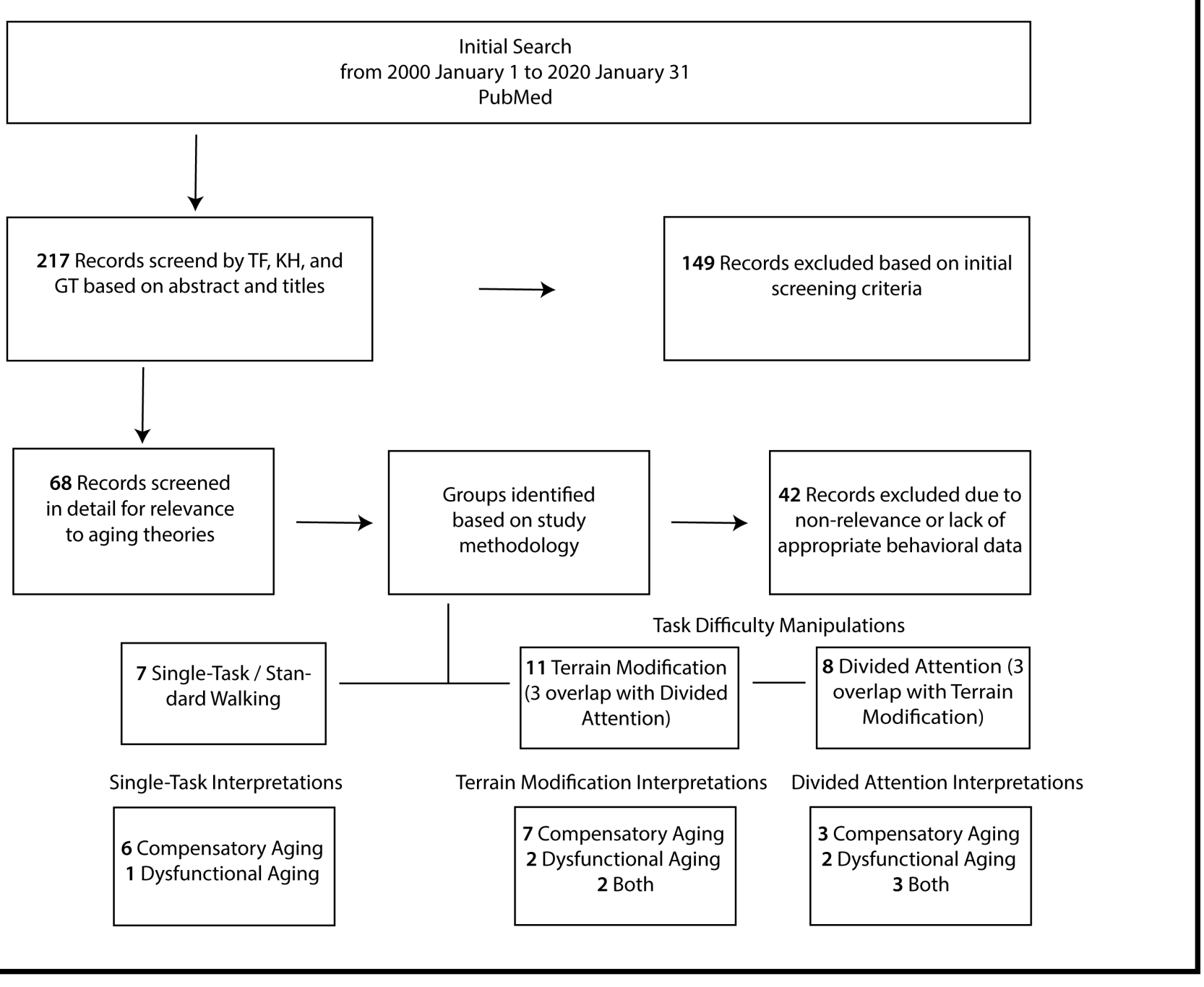

Figure 2: Diagram displaying the progression of systematic search results through multiple levels of inclusion and exclusion filtering. We then separated the included articles into three groups (Single Task Walking, Terrain Modification, and Divided Attention Modification) based on their experimental methods and determined whether the results follow compensatory vs. dysfunctional patterns.

\section{Results}

\subsection{Single-Task Assessments}

The single-task walking category included seven studies that tested associations between brain activity and walking. Four studies measured fluorodeoxyglucose (FDG) uptake via PET after over ground walking. (Mitchell et al., 2019; Sakurai et al., 2014, 2017; Shimada et al., 2013).

Participants were injected with FDG contrast, performed a walking task, and then completed a PET scan to measure FDG uptake, permitting identification of task-related brain regions. Three studies quantified brain activity during an unrelated (typically cognitive) task using fMRI and tested 
associations with walking performance outside of the MRI scanner (Fernandez et al., 2019; Jor'dan et al., 2017; Kawagoe et al., 2015).

Single-Task studies that support compensation: All of the studies that evaluated brain activity during walking found an association between increased brain activity and better or sustained performance for the older adults relative to young adults (Jor'dan et al., 2017; Kawagoe et al., 2015; Mitchell et al., 2019; Sakurai et al., 2014, 2017; Shimada et al., 2013). Two studies that acquired brain activity separately from walking also provide support for neural compensation with older age by showing that greater brain activity during the cognitive tasks in the scanner was associated with better walking performance outside the scanner (Jor'dan et al., 2017; Kawagoe et al., 2015). Single-Task studies that support dysfunction: Only one out of the seven single-task walking studies supported neural dysfunction with advancing age. Among a cohort of older adults, this study found an association between increased recruitment of parietal-occipital and precuneus regions during the flanker task and higher gait variability outside of the MRI scanner (Fernandez et al. 2019).

In sum, six out of seven articles in Single Task Assessments support that over-activation in older adults serves a compensatory function. That is, higher levels of brain activity corresponded to better walking performance. Conversely, one experiment measuring fMRI during the flanker task revealed over-activation was associated with poorer walking performance, consistent with a dysfunctional pattern.

\subsection{Task Difficulty Manipulations}

\subsubsection{Terrain Modifications}

Assessing differences in brain activity across multiple degrees of walking difficulty can help to identify whether levels of brain activity increase with increasing difficulty, reach a ceiling and asymptote, or possibly an inflection point where activity declines. By relating brain activity acquired during multiple difficulty levels to task performance, it becomes possible to unpack whether over-activation is compensatory and beneficial at some levels, but less so at others-- at very high levels of task difficulty for example. We identified four studies that recorded brain activity while participants negotiated obstacles while walking (Chen et al., 2017; Clark, Rose, et al., 2014; Hawkins et al., 2018; Mirelman et al., 2017). In additional studies, the authors changed the complexity of the walking task by providing auditory or visual cues for stepping (Clark, Christou, et al., 2014; Osofundiya et al., 2016; Spedden et al., 2019; Vitorio et al., 2018). Two experiments included imagined walking over obstacles or uneven terrain (Allali et al., 2014; Wai et al., 2012). Finally, two studies measured walking over obstacles (Gonzalez-Burgos et al., 2019) and walking with visual cues (Osofundiya et al., 2016) and tested for associations with separately acquired functional brain activity.

Terrain modification studies that support compensation: Four articles that measured brain activity during a modified terrain walking task support an interpretation of neural compensation (Clark, Christou, et al., 2014; Clark, Rose, et al., 2014; Spedden et al., 2019; Vitorio et al., 2018). That is, greater brain activity in the PFC was associated with better walking performance for older adults. Studies that measured brain activity during imagined walking over obstacles and uneven terrain also reported compensatory brain activity patterns (Allali et al., 2014; Wai et al., 2012). Greater activation in supplementary motor area, dorsolateral frontal, and frontoparietal regions was associated with better performance of imagined walking over obstacles (i.e. shorter time to complete the imagined walking course) and uneven terrain. Additionally, one of the two articles that tested for associations with separately acquired functional brain activity also provides support that overactivation in older adults is compensatory (Gonzalez-Burgos et al. 2019).

Terrain modification studies that support dysfunction: Two studies that reported brain activity acquired during obstacle crossing (Hawkins et al. 2018) or cued walking (Osofundiya et al. 2016) 
found an association between increased brain activity in PFC and poorer performance, suggesting neural dysfunction.

Terrain modification studies with ambiguous classification: Two experiments included an obstacle avoidance task that could be interpreted to support either compensation or dysfunction. Mirelman et al. (2017) showed greater PFC activation for old compared to young adults, but did not find significant performance decrements during obstacle crossing. This suggests that the identified higher levels of PFC activity served a compensatory function in older adults. However, the authors also reported an association between increased PFC activity and greater gait variability (often associated with balance difficulties (Hausdorff et al., 2001)). This suggests that increased PFC activity could also reflect neural dysfunction that underlies greater gait variability. Chen et al. (2017) introduced flat red areas on the ground (i.e., obstacles) for participants to avoid and reported increased PFC activity during obstacle walking compared to normal walking in older adults. They also found that slow compared to fast walkers showed both increased PFC activation and smaller reductions in gait speed during obstacle walking compared to fast walkers, suggestive of compensation. However, an alternative argument points to neural dysfunction, as the already diminished performance in the slow group might limit the additional cost of the obstacles.

Seven of the eleven articles in this category support that over-activation in older adults is compensatory for locomotion. Two articles present findings that are consistent with neural dysfunction, and an additional two reported data that could be interpreted as supporting either neural dysfunction or compensation. Thus, the majority of articles in the Terrain Modification category support compensation. However, importantly, no experimental design included multiple levels of terrain modification, which would have permitted investigation of whether neural compensation reaches a ceiling.

\subsubsection{Divided Attention Modifications}

Each of the studies in this category used fNIRs to measure PFC brain activity during single and dual task walking. Dual task walking involved secondary tasks to divide attention. Secondary tasks included reciting alternate letters of the alphabet, checking boxes on a paper, walking while talking, and walking while subtracting by sevens.

Divided attention studies that support compensation: Three studies provided evidence that increased PFC activity during dual task walking, compared to normal walking, relates to better walking performance (Beurskens et al., 2014; Holtzer et al., 2015; Stuart et al., 2019). Overall, these findings suggest PFC activity during cognitively demanding walking in older age.

Divided attention studies that support dysfunction: In a cohort of older adults, Osofundiya et al. (2016) found that gait speed slowed by about 30-40\% and PFC activity increased by 2-3.5 times as task complexity increased (normal walking vs. dual-task walking). This could be attributed to neural dysfunction, as greater PFC activity was associated with slower gait speeds in the more complex task conditions. Mirelman et al., (2017) revealed increased PFC activity for older versus young adults when walking while talking versus walking alone compared to young adults. This study also found greater gait variability during walking while talking in older adults relative to younger adults, suggesting that this identified increased PFC activity reflects neural dysfunction.

Divided attention studies with ambiguous classification: Chen et al., (2017) found that participants with a smaller reduction in gait speed from standard walking to walking while talking showed greater PFC activity as task complexity increased. However, those older adults who walked slower across all task conditions also showed greater increases in PFC activity as task difficulty increased. Potentially, these individuals were recruiting more neural resources, but not performing better than their peers who walked faster. Holtzer et al., (2016) found that greater PFC activity during dual task walking associated with better performance on the secondary cognitive task (reciting 
alternate letters of the alphabet), which could be interpreted as neural compensation. However, increased brain activity was not associated with gait speed during the dual task walking, suggesting that over-activation reflects neural dysfunction. Holtzer et al., (2019) found that PFC activity decreases with practice of dual-task walking for older adults, regardless of self-reported fear of falling. This indicates that initially older adults may increase PFC activity to maintain performance; then, as learning progresses, fewer cognitive resources are required. However, those who reported a fear of falling had greater increases in PFC activity from normal walking to dual task walking. These individuals also showed less decrease in PFC activity through repeated trials, suggesting dysfunctional brain activity patterns.

In summary, three articles in the Divided Attention category support compensation, two articles support dysfunction, and an additional three provide evidence for both compensation and neural dysfunction in older adults. Thus, compared to the other categories, the Divided Attention articles provide weaker support for the notion that over-activation in older adults reflects compensation.

\section{Discussion}

In the present review we aimed to 1) identify recent studies combining neuroimaging and measurement of mobility and 2) interpret these findings in the context of two key cognitive brain-aging theories. Recent technological advancements have enabled the combination of mobility and neuroimaging studies. We reviewed publications from the past two decades that involved neuroimaging and mobility measurements in older adults. We interpreted the findings in the context of two of the most common brain-aging hypotheses posited to explain over-activation in older relative to younger adults: neural dysfunction and neural compensation. We organized the studies into three main categories based on methodology, 1) Single Task Assessment, 2) Task Difficulty Manipulation: Terrain Modification, and 3) Task Difficulty Manipulation: Divided Attention Modifications. Only a few of these experiments originally intended to interpret their findings in the context of the brain-aging theories. Thus, our review provides novel re-interpretation of existing data and we gain an understanding about how methodological considerations and outcome variables can influence interpretations in the context of brain aging.

Sixteen out of twenty-six experiments found that older adults exhibit compensatory patterns of brain activity. Five report patterns of dysfunctional brain activity and the final five have ambiguous interpretations. The overall pattern was as follows: Single Task (6 compensatory, 1 dysfunctional), Terrain Modification (7 compensatory, 2 dysfunctional, 2 both), and Divided Attention (3 compensatory, 2 dysfunctional, 3 both).

One way to understand the distribution of findings is in terms of the level of difficulty posed by the differing methodologies. According to a compensation framework (Reuter-Lorenz \& Cappell, 2008), when the demand is too great, resources may be insufficient to achieve adequate compensation (i.e. a resource ceiling). It follows that effective compensation will be more evident for easier to mid-range tasks, and less evident or successful as difficulty increases. It is likely the single task assessments are in a lower difficulty range for a generally healthy older adult population, but nonetheless they require increased brain activity for older adults to perform at similar levels to the young adults. The Terrain Modification methodologies vary, but most provide some form of obstacle to avoid, which increases task difficulty. For some participants, this may be enough to reach a ceiling of compensatory brain activation, hence a greater number of interpretations of dysfunction compared to the single task. Divided Attention has the greatest spread of result interpretations. Following the logic above, this reflects a greater number of people have reached their neural resource ceiling in these paradigms. 


\section{$\underline{5.1 \text { Limitations }}$}

There are several limitations to this review and the underlying experiments:

1) The interpretation of the studies' results in the context of the two conceptual accounts (compensation vs. dysfunction) is rather subjective. First, there are a variety of behavioral measures that are used, and it is not certain whether performance on one metric translates to another. Second, in the case in which an article's results support dysfunction, we don't know whether older adult walking performance would be even worse without the observed over-activation. One way to tease this apart in future studies is to implement multiple levels of task difficulty. This is discussed in more detail in section 5.2 below.

2) The majority of the studies quantified brain activity with fNIRS, which limited measurements to only PFC recordings. This provides an incomplete picture of how brain activity subserves task performance. For instance, while dual task walking could associate with increased PFC activation in aging, it could also associate with decreased activation in other brain regions (e.g., primary motor cortex). That is, with aging, some brain regions could show evidence of compensation in response to a more demanding task, while other brain regions could show evidence suggesting neural dysfunction or other patterns.

3) The divided attention paradigms use a variety of secondary tasks (i.e. verbal fluency, serial subtraction, etc.), which may recruit different brain regions from each other. Further, these secondary tasks may not recruit similar brain regions as the primary walking task. These issues likely lead to variability in study outcomes.

4) There is not a standard reference for determining inter-subject change in brain activity with varying difficulty conditions. Previous studies have used static baseline conditions of standing (Fraser et al., 2016; Holtzer et al., 2011; Mirelman et al., 2017) or sitting (Beurskens et al., 2014), which may have inflated findings. Indeed, when using standing as a baseline condition, it is unsurprising to find large increases in brain activity levels across all regions when young and older adults perform a motor task (i.e. walking), with greater response in PFC and primary motor cortex for older adults. Therefore, a static baseline comparison may not be appropriate and could explain previous significant PFC activity changes.

5) Most of the studies presented did not account for structural brain changes with age. Arguably, one of the most important missing components in many of these studies is a measure and characterization of structural integrity (Melie-Garcia et al., 2018). Even with healthy aging, total brain volume diminishes about $0.2-0.5 \%$ per year starting at age 35 (Hedman et al., 2012). This is a major consideration for determining whether brain activation is associated with less structural integrity ("less wiring, more firing") (Daselaar et al., 2015).

\section{$\underline{5.2 \text { In the Future }}$}

Moving forward, how should we test people for neural function during mobility tasks? Below we list some considerations for future experimental designs that also address the limitations discussed above:

1) Parametric variation of walking task difficulty is important for fully characterizing the relationship of behavioral performance to brain indices. For example, an older adult may show compensatory brain activity (relative to a young adult) in standard walking, but introducing an obstacle may result in increased brain activity and substantial reduction in performance due to the inability to perform the task. According to the framework discussed above, if we were only interested in the brain-behavior relationship during the obstacle 
condition, we would classify this as dysfunctional neural activation. However, by increasing the obstacles incrementally, accompanying changes in brain activity can be assessed, coupled with changes in walking performance, so that potential compensatory brain activity and its limitations can be identified. This methodology has been applied successfully in older adults in many cognitive experiments (Cappell et al., 2010; Carp et al., 2010; ReuterLorenz \& Cappell, 2008), and has recently been investigated in walking (Clark et al., 2019).

2) Terrain modification paradigms are promising for studying how the neural control of mobility changes with age. Terrain modifications are more likely to identify the neural controls of mobility as opposed to those involved in secondary task performance. Terrain modifications could include performing a mobility task across multiple difficulty levels to probe the gradation and limits of potential compensatory brain activity. The complexity can be adjusted using uneven terrain, obstacles, or even balance perturbations (e.g., simulated falls). These terrain modifications can also be implemented in motor imagery paradigms, similar to those discussed in the section Terrain Modification: Imagined Modification.

3) We emphasize the importance of quantifying brain structure along with functional activity. An increasingly common strategy is to combine structural and functional assessment, using structural MRI with fNIRS in the same subjects to determine the relationship between frontal gray matter volume and fNIRS-derived brain activation (Wagshul et al., 2019), allowing for normalization of brain activity to gray matter volume. This allows determination of whether brain activity during walking is associated with structural changes.

4) In order to develop a comprehensive understanding of the brain-behavior relationships, many factors must also be taken into consideration. Mobility requires the integration of multiple sensory systems including vision, vestibular, and proprioceptive systems (Peterka, 2002). Therefore, measurements of sensory function could inform individual differences in specific compensatory brain activity. Standard clinical tests such as Romberg eyes open and eyes closed is an efficient way to test vestibular and visual reliance for standing posture (Lanska \& Goetz, 2000). Further, tactile perception can be tested with tactile discrimination tests on the feet (e.g., Semmes-Weinstein monofilaments), which is one of many important components of somatosensory function for balance. Pain is also a sensory system that can contribute to mobility and brain function (Brumagne et al., 2019), and can be efficiently and reliably measured with a general survey of pain experienced when performing the task of interest (Cruz-Almeida et al., 2017). All of these factors contribute to the individual variability in mobility function and are likely to influence compensatory and dysfunctional brain processes as well.

5) With increased understanding of how different brain areas contribute to mobility with age, we can potentially implement targeted neural interventions aimed at maintenance of mobility. For example, noninvasive brain stimulation coupled with mobility training can enhance performance. While we know some older adults may present more with neural compensation and others with neural dysfunction, a better understanding of these processes may allow for targeting different brain regions across individuals as a result.

\section{Conclusion}

The past two decades have brought numerous advances in the science of aging mobility. New technology has enabled the acquisition of novel types of data that can inform the neural underpinnings of mobility changes throughout the life span. Building on theoretical progress in neurocognitive aging, we applied two accounts of brain aging-neural compensation and neural dysfunction - to classify the results of published studies that combined brain activity and mobility measurements in older adults, dating back two decades. We separated the identified articles into three categories based on methodology: Single Task Assessment, Terrain Modifications, and Divided 
Attention Modifications. The Single Task Assessment category had the greatest proportion of results that supported compensation, followed by Terrain Modification, and finally Divided Attention. We recommend that future mobile imaging studies include multiple levels of walking complexity, structural brain images, and detailed participant history in order to understand whether the neural mechanisms associated with performance are compensatory or dysfunctional. This knowledge will lead to the ability to appropriately promote beneficial brain activity for the behavior of interest. 
Table 4. Single Task Assessments

\begin{tabular}{|c|c|c|c|c|c|}
\hline Citation & Participants & $\begin{array}{c}\text { Imaging } \\
\text { Techniques }\end{array}$ & $\begin{array}{c}\text { Behavioral } \\
\text { Measures }\end{array}$ & Primary Results & Aging Theory \\
\hline $\begin{array}{l}\text { (Fernandez et } \\
\text { al., 2019) }\end{array}$ & $\begin{array}{l}\text { Young Adults: } n= \\
21,100 \% \mathrm{~F}, 21 \pm 2.5 \\
\text { years } \\
\text { Older Adults: }=34 \\
100 \% \mathrm{~F}, 72 \pm 5.3 \\
\text { years }\end{array}$ & fMRI & $\begin{array}{l}\text { 1) Flanker } \\
\text { task } \\
\text { 2) TUG } \\
\text { 3) SPPB } \\
\text { 4) Gait } \\
\text { analysis }\end{array}$ & $\begin{array}{l}\text { Behavior: OAs had lower accuracy in } \\
\text { the flanker, with a higher accuracy cost, } \\
\text { and slower reaction time compared to } \\
\text { YAs. } \\
\text { Brain: OAs \& YAs greater recruitment } \\
\text { within the fronto-parietal-occipital } \\
\text { network during the incongruent } \\
\text { distractors on the flanker task. OAs had } \\
\text { increased activation in dorsal parieto- } \\
\text { occipitial sulcus and precuneus areas } \\
\text { relative to YA's. } \\
\text { Brain-Behavior Associations: } \\
\text { Increased recruitment of left dorsal } \\
\text { parieto-occipital sulcus and precuneus } \\
\text { associated with higher gait variability. }\end{array}$ & $\begin{array}{l}\text { Dysfunction: } \\
\text { Increased recruitment } \\
\text { of parietal-occipital } \\
\text { and precuneus areas } \\
\text { associated with } \\
\text { higher gait variability } \\
\text { in older adults. }\end{array}$ \\
\hline $\begin{array}{l}\text { (Jor'dan et al., } \\
2017)\end{array}$ & $\begin{array}{l}\text { Older Adults: } n=27 \text {, } \\
74 \% \text { F, } 70+\text { years }\end{array}$ & fMRI & $\begin{array}{l}\text { 1) N-back } \\
\text { 2) TCD } \\
\text { ultrasound } \\
\text { 3) Preferred } \\
\text { pace walking }\end{array}$ & $\begin{array}{l}\text { Brain-Behavior Associations: } \\
\text { Activation in DAN and executive } \\
\text { networks were associated with task- } \\
\text { related brain activity changes and } \\
\text { walking speed. }\end{array}$ & $\begin{array}{l}\text { Compensation: } \\
\text { Greater activation } \\
\text { with better n-back } \\
\text { performance and } \\
\text { also associated with } \\
\text { faster gait speed. }\end{array}$ \\
\hline $\begin{array}{l}\text { (Kawagoe et al., } \\
\text { 2015) }\end{array}$ & $\begin{array}{l}\text { Older Adults: } n=32 \text {, } \\
37.5 \% \mathrm{~F}, 73.06 \pm \\
4.83 \text { years }\end{array}$ & fMRI & $\begin{array}{ll}\text { 1) } & \text { TUG } \\
\text { 2) } & 10 \mathrm{~m} \text { walk } \\
\text { 3) } & \text { Nback test }\end{array}$ & $\begin{array}{l}\text { Brain: Increased brain activity as nback } \\
\text { difficulty increased. } \\
\text { Brain-Behavior Associations: } \\
\text { Thalamus, putamen, and cerebellum } \\
\text { activation during nback task positively } \\
\text { associated with TUG performance. }\end{array}$ & $\begin{array}{l}\text { Compensation: OAs } \\
\text { who had increased } \\
\text { activity in subcortical } \\
\text { regions performed } \\
\text { better on mobility } \\
\text { tasks. }\end{array}$ \\
\hline $\begin{array}{l}\text { (Mitchell et al., } \\
\text { 2019) }\end{array}$ & $\begin{array}{l}\text { Young Adults: } n=7 \\
4 \mathrm{~F}, 24 \pm 3 \text { years } \\
\text { Older Adults: } n=7 \\
3 \mathrm{~F}, 59 \pm 2 \text { years }\end{array}$ & FDG-PET & 1) Gait speed & $\begin{array}{l}\text { Behavioral: Similar walking } \\
\text { performance between OA's and YA's. } \\
\text { Brain: OAs had increased precentral } \\
\text { and fusiform gyri, reduced deactivation } \\
\text { of multisensory cortices (inferior frontal, } \\
\text { postcentral, and fusiform gyri), and } \\
\text { reduced activation of the middle frontal } \\
\text { gyrus and cuneus }\end{array}$ & $\begin{array}{l}\text { Compensation: OAs } \\
\text { increase the use of } \\
\text { the multisensory } \\
\text { cortices and frontal } \\
\text { brain regions } \\
\text { compared to YAs, } \\
\text { likely in order to }\end{array}$ \\
\hline
\end{tabular}




\begin{tabular}{|c|c|c|c|c|c|}
\hline & & & & & $\begin{array}{l}\text { maintain similar } \\
\text { walking performance. }\end{array}$ \\
\hline $\begin{array}{l}\text { (Sakurai et al., } \\
\text { 2014) }\end{array}$ & $\begin{array}{l}\text { Older Adults: } n= \\
182,100 \% \mathrm{~F}, 69.4 \pm \\
6.6 \text { years }\end{array}$ & FDG-PET & $\begin{array}{l}\text { 1) Gait speed } \\
\text { 2) Step length } \\
\text { 3) Step } \\
\text { frequency }\end{array}$ & $\begin{array}{l}\text { Brain-Behavior Associations: Slower } \\
\text { max gait speed was associated with } \\
\text { lower normalized-rCMRglc in prefrontal, } \\
\text { posterior cingulate and parietal cortices. }\end{array}$ & $\begin{array}{l}\text { Dysfunction: Those } \\
\text { that had worse gait } \\
\text { performance had } \\
\text { impaired uptake of } \\
\text { FDG, thus the } \\
\text { responsible regions } \\
\text { were inefficiently } \\
\text { accessing necessary } \\
\text { resources to maintain } \\
\text { performance }\end{array}$ \\
\hline $\begin{array}{l}\text { (Sakurai et al., } \\
2017 \text { ) }\end{array}$ & $\begin{array}{l}\text { Older Adults: } n= \\
149,100 \% \mathrm{~F}, 70.1 \pm \\
6.2 \text { years }\end{array}$ & FDG-PET & $\begin{array}{l}\text { 1) Gait speed } \\
\text { 2) Step length } \\
\text { 3) Cadence } \\
\text { during } \\
\text { preferred and } \\
\text { fast walking }\end{array}$ & $\begin{array}{l}\text { Brain-Behavior Associations: Slower } \\
\text { gait speed and lower cadence } \\
\text { associated with lower activity in } \\
\text { posterior cingulate, primary } \\
\text { sensorimotor, occipital, and parietal } \\
\text { cortices. }\end{array}$ & $\begin{array}{l}\text { Compensation: OAs } \\
\text { that reduced activity } \\
\text { in these key neural } \\
\text { control areas suffered } \\
\text { from diminished } \\
\text { mobility performance, } \\
\text { which means those } \\
\text { that activate areas } \\
\text { will improve } \\
\text { performance. }\end{array}$ \\
\hline $\begin{array}{l}\text { (Shimada et al., } \\
\text { 2013) }\end{array}$ & $\begin{array}{l}\text { Older Adults: } n= \\
24,100 \% \mathrm{~F}, 78 \pm 2.3 \\
\text { years }\end{array}$ & FDG-PET & $\begin{array}{l}\text { 1) Step length } \\
\text { variability }\end{array}$ & $\begin{array}{l}\text { Brain-Behavior Associations: Greater } \\
\text { step length variation associated with } \\
\text { deactivation of SMA and DLPFC. }\end{array}$ & $\begin{array}{l}\text { Dysfunction: Those } \\
\text { that had the greater } \\
\text { step length variability } \\
\text { were less able to } \\
\text { access the essential } \\
\text { neural resources }\end{array}$ \\
\hline
\end{tabular}

Note $\mathbf{M}=$ male $. \mathbf{F}=$ female $. \mathbf{O A}=$ Older Adults. $\mathbf{Y A}=$ Younger Adults. $\mathbf{S M A}=$ supplementary motor area. $\mathbf{r C M R g l \mathbf { c }}=$ regional cerebral metabolic rate of glucose consumption. $\mathrm{PFC}=$ prefrontal cortex. SPPB $=$ short physical performance battery.

aDenotes paper that is also included in the Task Difficulty Manipulation: Divided Attention category. In this table, we discuss only the results relevant to the gait-task modulation. In Table 2, we discuss the results relevant to the divided attention modification. 
Table 5. Task Difficulty Manipulation: Terrain Modification

\begin{tabular}{|c|c|c|c|c|c|}
\hline Citation & Participants & $\begin{array}{l}\text { Imaging } \\
\text { Techniques }\end{array}$ & $\begin{array}{l}\text { Behavioral } \\
\text { Measures }\end{array}$ & Primary Results & Aging Theory \\
\hline (Allali et al., 2014) & $\begin{array}{l}\text { Young Adults: } \\
n=14 ; 71 \% \mathrm{~F} ; \\
27.0 \pm 3.6 \text { years } \\
\\
\text { Older Adults: } \\
n=14 ; 71 \% \mathrm{~F} ; \\
66.0 \pm 3.5 \text { years }\end{array}$ & fMRI & $\begin{array}{l}\text { Motor imagery of } \\
\text { gait }+ \text { control } \\
\text { imagery task } \\
\text { (visual imagery } \\
\text { task); varied task } \\
\text { complexity. Also } \\
\text { performed Stroop } \\
\text { task. }\end{array}$ & $\begin{array}{l}\text { Behavioral: Older adults did } \\
\text { not show change in } \\
\text { performance (time to complete } \\
\text { walking path) based on } \\
\text { complexity. } \\
\text { Brain: YA and OA recruited } \\
\text { network of motor, frontal, \& } \\
\text { cerebellar regions during gait } \\
\text { imagery task. Age-related } \\
\text { increase in brain activity during } \\
\text { gait imagery in several regions: } \\
\text { right SMA, right orbitofrontal } \\
\text { cortex, and left dorsolateral } \\
\text { frontal cortex. Activity in the left } \\
\text { hippocampus was related to } \\
\text { task complexity in OAs only. }\end{array}$ & $\begin{array}{l}\text { Compensation: } \\
\text { Activation in non-task } \\
\text { specific regions is a } \\
\text { compensatory } \\
\text { recruitment for the } \\
\text { inability to perform the } \\
\text { cobblestone imagery } \\
\text { properly (did not show a } \\
\text { task complexity } \\
\text { interaction, i.e. longer } \\
\text { time). }\end{array}$ \\
\hline $\begin{array}{l}\text { (Chen et al., } \\
2017)^{\mathrm{a}}\end{array}$ & $\begin{array}{l}\text { Older Adults: } \\
n=90 ; 57 \% \text { F; } \\
78.1 \pm 5.5 \text { years }\end{array}$ & fNIRS & $\begin{array}{l}\text { Normal pace walk } \\
\text { and obstacle } \\
\text { negotiation (gait } \\
\text { speed). Obstacle } \\
\text { negotiation was } \\
\text { red shapes on } \\
\text { ground to avoid. }\end{array}$ & $\begin{array}{l}\text { Behavioral: Gait speed was } \\
\text { slower during Obstacle } \\
\text { Negotiation (ON) compared to } \\
\text { Normal Walking (NW). Slow } \\
\text { walkers had less of a decrease } \\
\text { in speed from NW to ON } \\
\text { compared to fast walkers. } \\
\text { Brain: Increased PFC } \\
\text { activation in ON condition } \\
\text { compared to NW. } \\
\text { Brain Behavior Associations: } \\
\text { Slow walking moderated brain } \\
\text { activity increase from NW to } \\
\text { ON, while people with slow gait } \\
\text { had higher activity during NW } \\
\text { compared to fast walkers. }\end{array}$ & $\begin{array}{l}\text { Compensation: The } \\
\text { slow group had smaller } \\
\text { obstacle costs (velocity) } \\
\text { compared to normal, } \\
\text { with greater PFC } \\
\text { activation. } \\
\text { Dysfunction: The slow } \\
\text { group was slower across } \\
\text { all conditions, which } \\
\text { could be indicative of } \\
\text { dysfunctional activation. }\end{array}$ \\
\hline
\end{tabular}




\begin{tabular}{|c|c|c|c|c|c|}
\hline $\begin{array}{l}\text { (Clark, Christou, } \\
\text { et al., 2014) }\end{array}$ & $\begin{array}{l}\text { Older Adults: } \\
n=14 ; \text { sex not } \\
\text { reported; } 77.1 \pm \\
5.56 \text { years }\end{array}$ & fNIRS & $\begin{array}{l}\text { Treadmill walking } \\
\text { and overground } \\
\text { walking--wearing } \\
\text { normal shoes, } \\
\text { wearing textured } \\
\text { insoles, and } \\
\text { wearing no shoes. }\end{array}$ & $\begin{array}{l}\text { Brain: Textured insoles } \\
\text { (increased somatosensory } \\
\text { input) resulted in reduced } \\
\text { prefrontal activity in both } \\
\text { hemispheres for both treadmill } \\
\text { \& overground walking. No } \\
\text { shoes (increased } \\
\text { somatosensory input) resulted } \\
\text { in REDUCED prefrontal activity } \\
\text { in both hemispheres for } \\
\text { treadmill walking only. }\end{array}$ & $\begin{array}{l}\text { Compensation: } \\
\text { Increased proprioception } \\
\text { (textured insoles) } \\
\text { decreases prefrontal } \\
\text { activity possibly } \\
\text { indicating prefrontal } \\
\text { activation is inherently } \\
\text { meant to compensate for } \\
\text { diminished } \\
\text { proprioception at the } \\
\text { sensor level. }\end{array}$ \\
\hline $\begin{array}{l}\text { (Clark, Rose, et } \\
\text { al., 2014) }\end{array}$ & $\begin{array}{l}\text { Older Adults: } \\
n=16 ; 50 \% \mathrm{~F} \\
77.2 \pm 5.6 \text { years }\end{array}$ & fNIRS & $\begin{array}{l}\text { Subjects walked at } \\
\text { preferred speed } \\
\text { (control task) + } \\
\text { walked on the } \\
\text { same course } \\
\text { under } 5 \text { separate } \\
\text { challenging } \\
\text { conditions: } \\
\text { performing a } \\
\text { cognitive verbal } \\
\text { fluency task, dim } \\
\text { lighting, carrying a } \\
\text { tray, negotiating } \\
\text { obstacles, and } \\
\text { wearing a } \\
\text { weighted vest. }\end{array}$ & $\begin{array}{l}\text { Brain: Higher prefrontal activity } \\
+ \text { higher skin conductance level } \\
\text { during the preparation phase of } \\
\text { complex walking tasks relative } \\
\text { to the control task. This } \\
\text { elevation of prefrontal activity } \\
\text { remained during performance } \\
\text { of the complex tasks. Brain- } \\
\text { Behavior Associations: } \\
\text { Larger } \\
\text { increase in prefrontal activity } \\
\text { was found to be linked to } \\
\text { "better" gait during complex } \\
\text { walking tasks }\end{array}$ & $\begin{array}{l}\text { Compensation: } \\
\text { Increased prefrontal } \\
\text { activity was linked to } \\
\text { better performance } \\
\text { during the complex } \\
\text { walking tasks. }\end{array}$ \\
\hline
\end{tabular}




\begin{tabular}{|c|c|c|c|c|c|}
\hline $\begin{array}{l}\text { (Gonzalez et al., } \\
\text { 2019) }\end{array}$ & $\begin{array}{l}\text { Older Adults: } n= \\
20,55 \% \mathrm{~F}, 63-80 \\
\text { years }\end{array}$ & fMRI & $\begin{array}{l}\text { Performed normal } \\
\text { speed walking, } \\
\text { fast walking, and } \\
\text { walking over } \\
\text { obstacles. }\end{array}$ & $\begin{array}{l}\text { Brain-Behavior Associations: } \\
\text { Brain activity change } \\
\text { associated with preferred gait } \\
\text { pace, particularly bilateral } \\
\text { precuneus changes with fast } \\
\text { pace gait, fast walking over } \\
\text { obstacles, and } 400 \mathrm{~m} \text { walk time. } \\
\text { Brain activity change in } \mathrm{L} \text { mid } \\
\text { frontal gyrus during spatial task } \\
\text { associated with preferred gait. }\end{array}$ & $\begin{array}{l}\text { Compensation: OAs } \\
\text { that performed better } \\
\text { had increased positive } \\
\text { brain activity changes. }\end{array}$ \\
\hline $\begin{array}{l}\text { (Hawkins et al., } \\
\text { 2018) }\end{array}$ & $\begin{array}{l}\text { Young Adults: } \\
n=9 ; 56 \% \text { F; } 22.4 \\
\pm 3.21 \text { years } \\
\\
\text { Older Adults: } \\
n=15 ; 53 \% \mathrm{~F} ; \\
77.2 \pm 5.6 \text { years }\end{array}$ & fNIRS & $\begin{array}{l}\text { Three walking } \\
\text { difficulties, typical } \\
\text { walking, over } \\
\text { obstacles }\end{array}$ & $\begin{array}{l}\text { Behavioral: Older adults had } \\
\text { an increased obstacle cost } \\
\text { (slower speed) } \\
\text { Brain: Significant increase in } \\
\text { PFC activity during typical and } \\
\text { obstacles for OA, increases in } \\
\text { complexity=increase in } \\
\text { activation for OAs and } \\
\text { decrease in walking speed as } \\
\text { complexity increased. } \\
\text { Brain-Behavior Associations: } \\
\text { Increased PFC activation } \\
\text { accompanied by a steep drop } \\
\text { in walking speed with } \\
\text { introduction of obstacles. }\end{array}$ & $\begin{array}{l}\text { Dysfunction: The } \\
\text { authors argue the } \\
\text { increased PFC is } \\
\text { compensatory, but } \\
\text { because increased PFC } \\
\text { was accompanied with a } \\
\text { steep drop in walking } \\
\text { speed we classify this as } \\
\text { dysfunctional activation. }\end{array}$ \\
\hline
\end{tabular}




\begin{tabular}{|c|c|c|c|c|c|}
\hline $\begin{array}{l}\text { (Mirelman et al., } \\
2017)^{\mathrm{a}}\end{array}$ & $\begin{array}{l}\text { Young Adults: } \\
n=23 ; 57 \% \mathrm{~F} ; \\
30.9 \pm 3.7 \text { years } \\
\\
\text { Older Adults: } \\
n=20 ; 50 \% \mathrm{~F} ; \\
69.7 \pm 5.8 \text { years }\end{array}$ & fNIRS & $\begin{array}{l}\text { Usual walking and } \\
\text { obstacle } \\
\text { negotiation }\end{array}$ & $\begin{array}{l}\text { Behavioral: Older adults } \\
\text { typically had worse gait } \\
\text { measures (more variable). } \\
\text { Brain: Old adults increase PFC } \\
\text { brain activity in normal walking } \\
\text { compared to standing whereas } \\
\text { young do not. Both young and } \\
\text { old adults increase brain } \\
\text { activity in the obstacle } \\
\text { negotiation compared to } \\
\text { standing, but older adults } \\
\text { increase more. } \\
\text { Brain-Behavior Associations: } \\
\text { Increased PFC activation } \\
\text { associated with increased } \\
\text { variability in the older adults. }\end{array}$ & $\begin{array}{l}\text { Compensation: Older } \\
\text { adults increase } \\
\text { activation in the } \\
\text { presence of obstacles } \\
\text { compared to young } \\
\text { adults. Arguably } \\
\text { required to compensate } \\
\text { for lack of automaticity. } \\
\text { Dysfunction: Increased } \\
\text { activation was } \\
\text { associated with gait } \\
\text { variability, which could } \\
\text { indicate inefficiency. }\end{array}$ \\
\hline $\begin{array}{l}\text { (Osofundiya et } \\
\text { al., 2016) }\end{array}$ & $\begin{array}{l}\text { Older Adults: } \\
n=10 ; 80 \% \mathrm{~F} \\
80.6 \pm 7.5 \text { years }\end{array}$ & fNIRS & $\begin{array}{l}\text { Visually-guided } \\
\text { walking }\end{array}$ & $\begin{array}{l}\text { Behavioral: } \sim 30-40 \% \text { slower } \\
\text { gait speeds when compared to } \\
\text { the simple walking task. } \\
\text { Brain: Complex ambulatory } \\
\text { tasks were associated with } \sim 2- \\
3.5 \text { times greater PFC } \\
\text { oxygenation levels. }\end{array}$ & $\begin{array}{l}\text { Dysfunction: The } \\
\text { drastic drop in gait } \\
\text { speed with the precision } \\
\text { walking and increased } \\
\text { PFC oxygenation } \\
\text { suggests dysfunction. }\end{array}$ \\
\hline
\end{tabular}




\begin{tabular}{|c|c|c|c|c|c|}
\hline $\begin{array}{l}\text { (Spedden et al., } \\
\text { 2019) }\end{array}$ & $\begin{array}{l}\text { Young Adults: } \\
n=15 ; 53 \% ; 22.1 \pm \\
1.7 \text { years } \\
\text { Older Adults: } \\
n=15 ; 53 \% \mathrm{~F} ; \\
68.3 \pm 2.7 \text { years }\end{array}$ & EEG & $\begin{array}{l}\text { Visually guided } \\
\text { (VG) walking } \\
\text { versus normal } \\
\text { walking }\end{array}$ & $\begin{array}{l}\text { Behavioral: Old adults } \\
\text { typically had decreased } \\
\text { performance (number of } \\
\text { targets hit) compared to young. } \\
\text { Brain: Intramuscular } \\
\text { coherence was lower in older } \\
\text { people compared to young } \\
\text { participants during both tasks. } \\
\text { In addition, coherence was } \\
\text { generally greater during VG } \\
\text { than during normal walking } \\
\text { across age groups. } \\
\text { Brain-Behavior Associations: } \\
\text { Performance on the VG task } \\
\text { was associated with task- } \\
\text { related corticomuscular } \\
\text { coherence modulations within } \\
\text { the older group. }\end{array}$ & $\begin{array}{l}\text { Compensation: Older } \\
\text { individuals that } \\
\text { increased coherence } \\
\text { during the VG task } \\
\text { increased performance, } \\
\text { which is an argument for } \\
\text { compensation. }\end{array}$ \\
\hline $\begin{array}{l}\text { (Vitorio et al., } \\
\text { 2018) }\end{array}$ & $\begin{array}{l}\text { Young Adults: } \\
n=17 ; 53 \% \text { F; } \\
20.3 \pm 1.2 \text { years } \\
\\
\text { Older Adults: } \\
n=18 ; 50 \% \text { F; } \\
72.6 \pm 8.0 \text { years }\end{array}$ & fNIRS & $\begin{array}{l}\text { Walked on a } \\
\text { motorized } \\
\text { treadmill for } 5 \\
\text { minutes ( } 5 \text { trials } \\
\text { with alternating } \\
30 \text {-second blocks } \\
\text { of usual walking } \\
\text { and Rhythmic } \\
\text { Auditory Cueing } \\
\text { (RAC) walking) }\end{array}$ & $\begin{array}{l}\text { Behavioral: Gait variability } \\
\text { decreased during cued walking } \\
\text { relative to usual walking. } \\
\text { Brain: Prefrontal } \mathrm{HbO}_{2} \text { levels } \\
\text { increased during cued walking } \\
\text { relative to usual walking. Older } \\
\text { adults showed greater } \mathrm{HbO}_{2} \\
\text { levels in multiple motor regions } \\
\text { during cued walking although } \\
\text { the response reduced with } \\
\text { repeated exposure. } \\
\text { Brain-Behavior Associations: } \\
\text { In older adults, lower } \\
\text { depression scores, higher } \\
\text { cognitive functioning, and } \\
\text { reduced gait variability were } \\
\text { linked with increased } \mathrm{HbO}_{2} \\
\text { levels during RAC walking. }\end{array}$ & $\begin{array}{l}\text { Compensation: } \\
\text { Improved performance } \\
\text { was associated with } \\
\text { higher PFC } \mathrm{HbO}_{2} \text { levels } \\
\text { indicating compensation. }\end{array}$ \\
\hline
\end{tabular}




\begin{tabular}{|c|c|c|c|c|c|}
\hline (Wai et al., 2012) & $\begin{array}{l}\text { Young Adults: } \\
n=14 ; 50 \% \text { F; } \\
21.5 \pm 1.6 \text { years } \\
\\
\text { Older Adults: } \\
n=13 ; 46 \% \text { F; } \\
64.8 \pm 6.1 \text { years }\end{array}$ & fMRI & $\begin{array}{l}\text { Video clip of gait } \\
\text { initiation, stepping } \\
\text { over an obstacle } \\
\text { and gait } \\
\text { termination }\end{array}$ & $\begin{array}{l}\text { Brain: An extensive network of } \\
\text { bilateral SMA, PMd, posterior } \\
\text { parietal lobe and visual } \\
\text { association areas was } \\
\text { activated in the Old versus the } \\
\text { Young subjects. Increased } \\
\text { activation in bilateral pre-SMA, } \\
\text { PMd, ventral premotor area, } \\
\text { precentral, posterior parietal } \\
\text { lobes and visual association } \\
\text { areas were activated in the Old } \\
\text { when compared to the Young. }\end{array}$ & $\begin{array}{l}\text { Compensation: The } \\
\text { visual areas were } \\
\text { activated to a greater } \\
\text { extent throughout the } \\
\text { progression of the task } \\
\text { (YA<OA). Increased } \\
\text { reliance on visual areas } \\
\text { is compensatory } \\
\text { activation. }\end{array}$ \\
\hline
\end{tabular}

Note. $\mathbf{M}=$ male. $\mathbf{F}=$ female. $\mathbf{O A}=$ Older Adults. $\mathbf{Y A}=$ Younger Adults. SMA = supplementary motor area. $\mathbf{P M d}=$ dorsal premotor. $\mathbf{P F C}=$ prefrontal cortex.

aDenotes paper that is also included in the Task Difficulty Manipulation: Divided Attention category. In this table, we discuss only the results relevant to the gait-task modulation. In Table 2, we discuss the results relevant to the divided attention modification. 
Table 6. Task Difficulty Manipulation: Divided Attention

\begin{tabular}{|c|c|c|c|c|c|}
\hline Citation & Participants & $\begin{array}{l}\text { Imaging } \\
\text { Techniques }\end{array}$ & $\begin{array}{l}\text { Behavioral } \\
\text { Measures }\end{array}$ & Primary Results & Aging Theory \\
\hline $\begin{array}{l}\text { (Beurskens } \\
\text { et al., 2014) }\end{array}$ & $\begin{array}{l}\text { Young Adults: } \\
\mathrm{n}=15 ; \text { sex not } \\
\text { reported; } 24.5 \pm \\
3.3 \text { years } \\
\\
\text { Older Adults: } \\
\mathrm{n}=10 ; \text { sex not } \\
\text { reported; } 71.0 \pm \\
3.8 \text { years }\end{array}$ & $\begin{array}{l}\mathrm{fNIRS} \\
\text { (average } \\
\text { prefrontal } \\
\mathrm{HbO}_{2} \text { ) }\end{array}$ & $\begin{array}{l}\text { 1) TW } \\
\text { 2) Alpha } \\
\text { 3) Check } \\
\text { 3) TW + Alpha } \\
\text { 4) TW + Check }\end{array}$ & $\begin{array}{l}\text { Behavioral: OAs performed worse than } \\
\text { YAs on the secondary tasks (i.e., Alpha } \\
\text { and Check). Step duration increased } \\
\text { with increasing task complexity for OAs. } \\
\text { Greater dual task cost for some gait } \\
\text { measures for OAs compared to YAs } \\
\text { (e.g., step length shortened more and } \\
\text { and step duration lengthened more for } \\
\text { OAs than YAs during TW+Check and } \\
\text { TW+Alpha). } \\
\text { Brain Activity, YAs: Little activity } \\
\text { changes for prefrontal cortex from } \\
\text { single to dual task for both dual task } \\
\text { conditions. } \\
\text { Brain Activity, OAs: Substantial } \\
\text { decrease in prefrontal activity for OAs } \\
\text { during the most difficult task } \\
\text { (TW+Check). }\end{array}$ & $\begin{array}{l}\text { Compensation: Brain } \\
\text { activity maintained at a } \\
\text { similar level between TW } \\
\text { and the easier dual task } \\
\text { (TW+Alpha). However, for } \\
\text { OAs but not YAs, brain } \\
\text { activity decreased with } \\
\text { increasing task demand, as } \\
\text { seen at the most difficult } \\
\text { level of the task, the } \\
\text { TW+Check task. This could } \\
\text { indicate that, during the most } \\
\text { difficult task, the OAs } \\
\text { reached their resource } \\
\text { ceiling. Thus, the decreased } \\
\text { prefrontal activity could } \\
\text { represent a shift in } \\
\text { processing from frontal } \\
\text { regions to alternative brain } \\
\text { networks, to still allow for } \\
\text { performance of the dual } \\
\text { task. }\end{array}$ \\
\hline $\begin{array}{l}\text { (Chen et } \\
\text { al., 2017) }\end{array}$ & $\begin{array}{l}\text { Older Adults: } \\
n=90 ; 51 \% \mathrm{~F} \\
78.1 \pm 5.5 \text { years }\end{array}$ & $\begin{array}{l}\text { fNIRS } \\
\text { (average } \\
\text { prefrontal } \\
\mathrm{HbO}_{2} \text { ) }\end{array}$ & $\begin{array}{l}\text { 1) } \mathrm{NW} \\
\text { 2) } \mathrm{WWT} \\
\text { 3) } \mathrm{ON} \\
\text { 4) } \mathrm{WWT+ON}\end{array}$ & $\begin{array}{l}\text { Behavioral: Reduced gait speed during } \\
\text { WWT, ON, and WWT+ON. } \\
\text { Brain Activity: Increased prefrontal } \\
\text { activity during WWT compared to NW } \\
\text { and WWT+ON compared to ON. } \\
\text { Brain- Behavior Associations: } \\
\text { Compared to those with normal gait }\end{array}$ & $\begin{array}{l}\text { Compensation: The } \\
\text { increased prefrontal activity } \\
\text { seen with increased task } \\
\text { complexity suggests } \\
\text { compensation. Also, those } \\
\text { with slower gait had smaller } \\
\text { reductions in gait speed }\end{array}$ \\
\hline
\end{tabular}




\begin{tabular}{|c|c|c|c|c|c|}
\hline & & & & $\begin{array}{l}\text { speed, those with slow gait had smaller } \\
\text { reductions in gait speed paired with } \\
\text { greater activity during ON+WWT. }\end{array}$ & $\begin{array}{l}\text { paired and greater prefrontal } \\
\text { activity during more } \\
\text { challenging conditions, again } \\
\text { suggesting compensation. } \\
\text { Dysfunction: Those with } \\
\text { slow gait walked slower } \\
\text { across all task conditions, } \\
\text { which could suggest neural } \\
\text { dysfunction. }\end{array}$ \\
\hline $\begin{array}{l}\text { (Holtzer et } \\
\text { al., 2015) }\end{array}$ & $\begin{array}{l}\text { Older Adults: } \\
\mathrm{n}=348 ; 59 \% \mathrm{~F} \\
76.8 \pm 6.8 \text { years }\end{array}$ & $\begin{array}{l}\text { fNIRS } \\
\text { (average } \\
\text { prefrontal } \\
\mathrm{HbO}_{2} \text { ) }\end{array}$ & $\begin{array}{l}\text { 1) NW } \\
\text { 2) Alpha } \\
\text { 3) WWT }\end{array}$ & $\begin{array}{l}\text { Behavioral: Reduced stride length and } \\
\text { gait speed during WWT versus NW. } \\
\text { Brain Activity: Increased brain activity } \\
\text { for WWT versus NW. Elevated activity } \\
\text { was sustained throughout the entire } \\
\text { WWT trial. } \\
\text { Brain-Behavior Associations: During } \\
\text { WWT, higher activity related to } \\
\text { increased stride length and better } \\
\text { cognitive performance. Neither NW nor } \\
\text { WWT activity related to gait speed. }\end{array}$ & $\begin{array}{l}\text { Compensation: Greater } \\
\text { activity during WWT } \\
\text { suggests compensation (i.e., } \\
\text { increased brain activity to } \\
\text { adjust for greater task } \\
\text { complexity level). Increased } \\
\text { brain activity maintained } \\
\text { throughout the entire trial } \\
\text { suggests that more brain } \\
\text { resources are necessary for } \\
\text { supporting cognitively- } \\
\text { demanding walking (rather } \\
\text { than needed only to adapt to } \\
\text { the task at the start). The } \\
\text { relationship between } \\
\text { increased activity and better } \\
\text { gait (increased stride length) } \\
\text { and better cognitive } \\
\text { performance during WWT } \\
\text { further suggests } \\
\text { compensation. }\end{array}$ \\
\hline $\begin{array}{l}\text { (Holtzer et } \\
\text { al., 2016) }\end{array}$ & $\begin{array}{l}\text { Older Adults: } \\
\mathrm{n}=167 ; 51 \% \mathrm{~F} \\
74.4 \pm 6.0 \text { years }\end{array}$ & $\begin{array}{l}\text { fNIRS } \\
\text { (average } \\
\text { prefrontal } \\
\mathrm{HbO}_{2} \text { ) }\end{array}$ & $\begin{array}{l}\text { 1) NW } \\
\text { 2) Alpha } \\
\text { 3) WWT }\end{array}$ & $\begin{array}{l}\text { Behavioral: Slower gait speed during } \\
\text { WWT versus NW. Similar rate of correct } \\
\text { letters, but higher error rate in WWT } \\
\text { versus Alpha. } \\
\text { Brain Activity: Increased brain activity } \\
\text { from NW to Alpha to WWT. } \\
\text { Brain-Behavior Associations: } \text { Higher } \\
\text { levels of activity during WWT related to } \\
\text { better cognitive performance, but slower }\end{array}$ & $\begin{array}{l}\text { Compensation: Increased } \\
\text { prefrontal activity from NW } \\
\text { to Alpha to WWT suggests } \\
\text { that greater brain activity is } \\
\text { needed to support } \\
\text { performance of the cognitive } \\
\text { task, especially while } \\
\text { walking. Individuals } \\
\text { generated correct letters at a }\end{array}$ \\
\hline
\end{tabular}




\begin{tabular}{|c|c|c|c|c|c|}
\hline & & & & gait velocity. & $\begin{array}{l}\text { similar rate during WWT } \\
\text { compared to Alpha, } \\
\text { supporting that this is } \\
\text { compensatory over-activity. } \\
\text { Dysfunction: Increased } \\
\text { brain activity did not support } \\
\text { maintenance of gait speed } \\
\text { during WWT compared to } \\
\text { NW, suggesting that the } \\
\text { over-activity was not efficient } \\
\text { for maintaining gait } \\
\text { performance. }\end{array}$ \\
\hline $\begin{array}{l}\text { (Holtzer et } \\
\text { al., 2019) }\end{array}$ & $\begin{array}{l}\text { No Self- Reported } \\
\text { Fear of Falling } \\
\text { (FOF): } \\
\mathrm{n}=56 ; 45 \% \mathrm{~F} ; \\
76.7 \pm 6.4 \text { years } \\
\text { Self-Reported } \\
\text { Fear of Falling } \\
\text { (FOF): } \\
\mathrm{n}=19 ; 68 \% \mathrm{~F} ; \\
79.8 \pm 6.0 \text { years }\end{array}$ & $\begin{array}{l}\text { fNIRS } \\
\text { (average } \\
\text { prefrontal } \\
\mathrm{HbO}_{2} \text { ) }\end{array}$ & $\begin{array}{l}\text { 1) NW } \\
\text { 2) Alpha } \\
\text { 3) WWT } \\
\text { (3 trials of } \\
\text { each condition) }\end{array}$ & $\begin{array}{l}\text { Behavioral: FOF associated with } \\
\text { slower stride velocity. Stride velocity } \\
\text { slowed from NW to WWT. Across the } \\
\text { three trials of each condition, } \\
\text { participants increased stride velocity } \\
\text { and rate of correct letter generation. } \\
\text { Brain Activity, No FOF: Increased } \\
\text { brain activity from NW to WWT. activity } \\
\text { decreased over repeated trials for WWT } \\
\text { and Alpha. } \\
\text { Brain Activity, FOF: Increased brain } \\
\text { activity from NW to WWT. activity } \\
\text { decreased over repeated trials for WWT } \\
\text { and Alpha. } \\
\text { Comparison of No FOF to FOF: } \\
\text { Increased brain activity during WWT for } \\
\text { the FOF group compared to the no FOF } \\
\text { group. Brain activity increased more } \\
\text { from NW to WWT for the FOF group. } \\
\text { FOF group saw less decline in activity } \\
\text { from the first to the second WWT trials. }\end{array}$ & $\begin{array}{l}\text { Compensation, no FOF: } \\
\text { Prefrontal activity increased } \\
\text { from NW to WWT to } \\
\text { compensate for the more } \\
\text { challenging task. Further, } \\
\text { activity decreased over } \\
\text { repeated trials; less brain } \\
\text { activity was needed to } \\
\text { support improved gait and } \\
\text { cognitive performance over } \\
\text { repeated trials. } \\
\text { Neural Dysfunction, FOF: } \\
\text { Greater increases in brain } \\
\text { activity from NW to WWT } \\
\text { and Alpha to WWT for the } \\
\text { FOF group suggests } \\
\text { dysfunction. The FOF group } \\
\text { required more brain activity } \\
\text { to support the dual task and } \\
\text { they performed worse (i.e., } \\
\text { they walked slower) than the } \\
\text { no FOF group. Less declines } \\
\text { in prefrontal activity from the } \\
\text { first to second WWT trials for } \\
\text { the FOF group also } \\
\text { suggests less improvement } \\
\text { in neural efficiency for these } \\
\text { groups with repeated }\end{array}$ \\
\hline
\end{tabular}




\begin{tabular}{|c|c|c|c|c|c|}
\hline & & & & & exposure to a task. \\
\hline $\begin{array}{l}\text { (Mirelman } \\
\text { et al., } \\
2017)^{\mathrm{a}}\end{array}$ & $\begin{array}{l}\text { Young Adults: } \\
\mathrm{n}=23 ; 57 \% \text { F; } \\
30.9 \pm 3.7 \text { years } \\
\\
\text { Older Adults: } \\
\mathrm{n}=20 ; 50 \% \text { F; } \\
69.7 \pm 5.8 \text { years }\end{array}$ & $\begin{array}{l}\text { fNIRS } \\
\text { (average } \\
\text { prefrontal } \\
\mathrm{HbO}_{2} \text { ) }\end{array}$ & $\begin{array}{l}\text { 1) Standing } \\
\text { 2) NW } \\
\text { 3) WWS }\end{array}$ & $\begin{array}{l}\text { Behavioral: Compared to YAs, OAs } \\
\text { performed worse on gait measures (i.e., } \\
\text { shorter stride length and slower gait } \\
\text { speed). YAs and OAs had similar } \\
\text { scores on the subtraction tasks. } \\
\text { Brain Activity, YAs vs. OAs: OAs had } \\
\text { higher levels of prefrontal activity } \\
\text { compared to YAs across all walking } \\
\text { conditions. Both groups had similar } \\
\text { increases in prefrontal activity from NW } \\
\text { to WWS. } \\
\text { Brain-Behavior Associations: Greater } \\
\text { prefrontal activity associated with } \\
\text { increased gait variability during NW and } \\
\text { WWS for OAs but not for YAs. }\end{array}$ & $\begin{array}{l}\text { Compensation: All } \\
\text { participants recruited more } \\
\text { neural resources to perform } \\
\text { the more difficult tasks, } \\
\text { suggesting that this } \\
\text { increased activation is } \\
\text { compensatory. Further, as a } \\
\text { compensatory mechanism, } \\
\text { OAs required greater } \\
\text { prefrontal activity to perform } \\
\text { each of the tasks compared } \\
\text { to YAs, even for the simplest } \\
\text { condition (NW). This } \\
\text { increased activation allowed } \\
\text { OAs to perform the NW and } \\
\text { WWS tasks at similar } \\
\text { proficiency compared to the } \\
\text { YAs (e.g., similar gait } \\
\text { variability). } \\
\text { Neural Dysfunction: } \\
\text { Increased prefrontal activity } \\
\text { during NW and WWS } \\
\text { associated with increased } \\
\text { gait variability. This could } \\
\text { represent neural dysfunction } \\
\text { in that increased brain } \\
\text { activity was not sufficient to } \\
\text { maintain performance in } \\
\text { either condition. }\end{array}$ \\
\hline $\begin{array}{l}\text { (Osofundiya } \\
\text { et al., } \\
2016)^{\text {a }}\end{array}$ & $\begin{array}{l}\text { Older Adults: } \\
\mathrm{n}=10 ; 80 \% \mathrm{~F} \\
80.6 \pm 7.5 \text { years }\end{array}$ & $\begin{array}{l}\text { fNIRS } \\
\text { (average } \\
\text { prefrontal } \\
\mathrm{HbO}_{2} \text { ) }\end{array}$ & $\begin{array}{l}\text { 1) NWW } \\
\text { 2) WWT }\end{array}$ & $\begin{array}{l}\text { Behavioral: Participants walked } 30- \\
40 \% \text { slower during WWT compared to } \\
\text { NW. } \\
\text { Brain Activity: WWT associated with 2- } \\
\text { 3.5x greater prefrontal activity } \\
\text { compared to NW. }\end{array}$ & $\begin{array}{l}\text { Neural Dysfunction: } \\
\text { Greater prefrontal activity } \\
\text { but substantially slower gait } \\
\text { speed during WWT } \\
\text { compared to NW suggests } \\
\text { neural dysfunction. The } \\
\text { greater recruitment of frontal } \\
\text { brain resources during WWT } \\
\text { did not allow participants to } \\
\text { maintain the same level of }\end{array}$ \\
\hline
\end{tabular}




\begin{tabular}{|c|c|c|c|c|c|}
\hline & & & & & behavioral performance. \\
\hline $\begin{array}{l}\text { (Stuart et } \\
\text { al., 2019) }\end{array}$ & $\begin{array}{l}\text { Young Adults: } \\
\mathrm{n}=17 ; 53 \% \mathrm{~F} ; \\
20.3 \pm 1.2 \text { years } \\
\\
\text { Older Adults: } \\
\mathrm{n}=18 ; 50 \% \mathrm{~F} ; \\
72.6 \pm 8.0 \text { years }\end{array}$ & $\begin{array}{l}\text { fNIRS (multiple } \\
\text { ROIs } \\
\text { examined } \\
\text { separately, left } \\
\text { and right: } \\
\text { prefrontal } \\
\text { cortex, M1, } \\
\text { SMA, and } \\
\text { PMC) }\end{array}$ & $\begin{array}{l}\text { 1) } T W \\
\text { 2) } D V \\
\text { 3) } T W+D V\end{array}$ & $\begin{array}{l}\text { Behavioral: No change in gait } \\
\text { performance between TW and TW+DV. } \\
\text { Brain Activity: Brain activity increased } \\
\text { during TW + DV in PMC, SMA, and M1, } \\
\text { but not in prefrontal cortex. There were } \\
\text { few group differences between YAs and } \\
\text { OAs during TW+DV. The only } \\
\text { differences were in left SMA. OAs did } \\
\text { not increase left SMA activity to the } \\
\text { same extent as YAs during TW+DV. } \\
\text { Brain-Behavior Associations: There } \\
\text { were no associations between brain } \\
\text { activity in any of the ROls and gait } \\
\text { measures. The only consistent } \\
\text { relationship was between greater } \\
\text { activity in most ROls during TW+DV } \\
\text { and better executive function } \\
\text { performance (measured using separate } \\
\text { cognitive tasks). } \\
\text { Effect of Repeated Trials: Brain } \\
\text { activity increased in response to } \\
\text { TW+DV primarily with the first task } \\
\text { exposure (i.e., Trials } 1 \text { and/or } 2 \text { of } 5 \text { ). } \\
\text { The response attenuated with } \\
\text { subsequent trials. }\end{array}$ & $\begin{array}{l}\text { Compensation: Increased } \\
\text { brain activity with increasing } \\
\text { task complexity but no } \\
\text { declines in gait performance } \\
\text { suggests compensation. The } \\
\text { association between better } \\
\text { executive function and } \\
\text { greater activity during the } \\
\text { dual task suggests that } \\
\text { those with better executive } \\
\text { function have a greater } \\
\text { capacity to increase activity } \\
\text { as a compensatory } \\
\text { measure. }\end{array}$ \\
\hline
\end{tabular}

Note. $\mathbf{M}=$ male $\mathbf{F}=$ female $. \mathbf{Y A}=$ younger adult. $\mathbf{O A}=$ older adult. $\mathbf{H b O}_{2}=$ cortical oxygenated hemoglobin. $\mathbf{F O F}=$ fear of falling. $\mathbf{R O I}=$ region of interest. $\mathbf{M} \mathbf{1}$ = primary motor cortex. SMA = supplementary motor area. $\mathbf{P M C}=$ premotor cortex.

aDenotes paper that is also included in the Task Difficulty Manipulation: Terrain Modification category. In this table, we discuss only the results relevant to divided attention. In Table 2, we discuss the results relevant to the modification of gait task complexity.

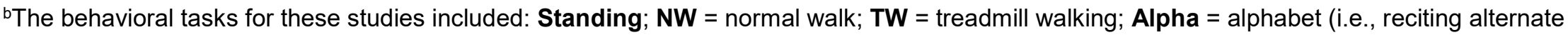
letters of the alphabet); Check = checking boxes on a sheet of paper; $\mathbf{T W}+\mathbf{A l p h a}=$ treadmill walking concurrently with alphabet task; TW+Check $=$ treadmill walking concurrently with checking task; WWT = walking while talking (i.e., while completing the Alpha task); WWS = walking while subtracting (e.g., performing serial subtractions by $3 \mathrm{~s}$ ); $\mathbf{O N}=$ obstacle negotiation; $\mathbf{O N}+\mathbf{W W T}=$ obstacle negotiation during the walking while talking task; $\mathbf{D V}=$ digit vigilance (i.e., counting how many times a given number was played on an audio recording); $\mathbf{T W}+\mathbf{D V}=$ treadmill walking 
concurrently with the digit vigilance task.

In addition to healthy older adults, this study also included individuals with peripheral and neurologic gait abnormalities. Here we report only the demographics, results, and aging theory conclusions relevant to the healthy older adults included in this study.

'In addition to healthy older adults, this study also included individuals with obesity. Here we report only the demographics, results, and aging theory conclusions relevant to the healthy older adults included in this sample. Additionally, this study included a condition (i.e., precision walking) that is included in the task-relevant category. In this table, we discuss only the methods and results relevant to the divided attention. In Table 1 , we discuss the results relevant to the modification of gait task complexity. 


\section{Consent for publication}

All authors provided approval for publication.

\section{Funding}

Supported by NIH (U01AG061389)

\section{Competing interests}

The authors declare that they have no competing interests.

\section{REFERENCES}

Allali, G., van der Meulen, M., Beauchet, O., Rieger, S. W., Vuilleumier, P., \& Assal, F. (2014). The neural basis of age-related changes in motor imagery of gait: An fMRI study. The Journals of Gerontology. Series A, Biological Sciences and Medical Sciences, 69(11), 1389-1398. https://doi.org/10.1093/gerona/glt207

Bäckman, L., \& Dixon, R. (1992). Psychological compensation: A theoretical framework. Psychological Bulletin, 112, 259-283. https://doi.org/10.1037/0033-2909.112.2.259

Baltes, P. B., \& Lindenberger, U. (1997). Emergence of a powerful connection between sensory and cognitive functions across the adult life span: A new window to the study of cognitive aging? Psychology and Aging, 12(1), 12-21. https://doi.org/10.1037/0882-7974.12.1.12

Bernard, J. A., \& Seidler, R. D. (2012). Evidence for motor cortex dedifferentiation in older adults. Neurobiology of Aging, 33(9), 1890-1899. https://doi.org/10.1016/j.neurobiolaging.2011.06.021

Beurskens, R., Helmich, I., Rein, R., \& Bock, O. (2014). Age-related changes in prefrontal activity during walking in dual-task situations: A fNIRS study. International Journal of Psychophysiology: Official Journal of the International Organization of Psychophysiology, 92(3), 122-128. https://doi.org/10.1016/j.jpsycho.2014.03.005

Brown, L. A., Sleik, R. J., Polych, M. A., \& Gage, W. H. (2002). Is the prioritization of postural control altered in conditions of postural threat in younger and older adults? Journals of 
Gerontology - Series A Biological Sciences and Medical Sciences, 57(12), 785-792. https://doi.org/10.1093/gerona/57.12.M785

Brumagne, S., Diers, M., Danneels, L., Moseley, G. L., \& Hodges, P. W. (2019). Neuroplasticity of Sensorimotor Control in Low Back Pain. Journal of Orthopaedic \& Sports Physical Therapy, 49(6), 402-414. https://doi.org/10.2519/jospt.2019.8489

Cabeza, R., Mangels, J., Nyberg, L., Habib, R., Houle, S., Mclntosh, A. R., \& Tulving, E. (1997). Brain regions differentially involved in remembering what and when: A PET study. Neuron, 19(4), 863-870. https://doi.org/10.1016/S0896-6273(00)80967-8

Cabeza, R., Prince, S. E., Daselaar, S. M., Greenberg, D. L., Budde, M., Dolcos, F., LaBar, K. S., \& Rubin, D. C. (2004). Brain activity during episodic retrieval of autobiographical and laboratory events: An fMRI study using a novel photo paradigm. Journal of Cognitive Neuroscience, 16(9), 1583-1594. https://doi.org/10.1162/0898929042568578

Calautti, C., Serrati, C., \& Baron, J. C. (2001). Effects of age on brain activation during auditorycued thumb-to-index opposition: A positron emission tomography study. Stroke, 32(1), 139-146. https://doi.org/10.1161/01.STR.32.1.139

Cappell, K., Gmeindl, L., \& Reuter-Lorenz, P. (2010). Age Differences in Prefontal Recruitment During Verbal Working Memory Maintenance Depend on Memory Load. https://doi.org/10.1038/mp.2011.182.doi

Carp, J., Gmeindl, L., \& Reuter-Lorenz, P. A. (2010). Age differences in the neural representation of working memory revealed by multi-voxel pattern analysis. Frontiers in Human Neuroscience, 4, 217. https://doi.org/10.3389/fnhum.2010.00217

Carp, J., Park, J., Hebrank, A., Park, D. C., \& Polk, T. A. (2011). Age-related neural dedifferentiation in the motor system. PloS One, 6(12), e29411. https://doi.org/10.1371/journal.pone.0029411

Cassady, K., Gagnon, H., Lalwani, P., Simmonite, M., Foerster, B., Park, D., Peltier, S. J., Petrou, M., Taylor, S. F., Weissman, D. H., Seidler, R. D., \& Polk, T. A. (2019). 
Sensorimotor network segregation declines with age and is linked to GABA and to sensorimotor performance. Neurolmage, 186, 234-244.

https://doi.org/10.1016/j.neuroimage.2018.11.008

Chen, M., Pillemer, S., England, S., Izzetoglu, M., Mahoney, J. R., \& Holtzer, R. (2017). Neural correlates of obstacle negotiation in older adults: An fNIRS study. Gait \& Posture, 58, 130-135. https://doi.org/10.1016/j.gaitpost.2017.07.043

Clark, D. J., Christou, E. A., Ring, S. A., Williamson, J. B., \& Doty, L. (2014). Enhanced somatosensory feedback reduces prefrontal cortical activity during walking in older adults. The Journals of Gerontology. Series A, Biological Sciences and Medical Sciences, 69(11), 1422-1428. https://doi.org/10.1093/gerona/glu125

Clark, D. J., Manini, T. M., Ferris, D. P., Hass, C. J., Brumback, B. A., Cruz-Almeida, Y., Pahor, M., Reuter-Lorenz, P. A., \& Seidler, R. D. (2019). Multimodal Imaging of Brain Activity to Investigate Walking and Mobility Decline in Older Adults (Mind in Motion Study): Hypothesis, Theory, and Methods. Frontiers in Aging Neuroscience, 11, 358. https://doi.org/10.3389/fnagi.2019.00358

Clark, D. J., Rose, D. K., Ring, S. A., \& Porges, E. C. (2014). Utilization of central nervous system resources for preparation and performance of complex walking tasks in older adults. Frontiers in Aging Neuroscience, 6, 217. https://doi.org/10.3389/fnagi.2014.00217

Cruz-Almeida, Y., Rosso, A., Marcum, Z., Harris, T., Newman, A. B., Nevitt, M., Satterfield, S., Yaffe, K., Rosano, C., \& for the Health ABC Study. (2017). Associations of Musculoskeletal Pain With Mobility in Older Adults: Potential Cerebral Mechanisms. The Journals of Gerontology: Series A, 72(9), 1270-1276. https://doi.org/10.1093/gerona/glx084

Daselaar, S. M., lyengar, V., Davis, S. W., Eklund, K., Hayes, S. M., \& Cabeza, R. E. (2015). Less wiring, more firing: Low-performing older adults compensate for impaired white 
matter with greater neural activity. Cerebral Cortex, 25(4), 983-990.

https://doi.org/10.1093/cercor/bht289

Davis, S. W., Kragel, J. E., Madden, D. J., \& Cabeza, R. (2012). The architecture of crosshemispheric communication in the aging brain: Linking behavior to functional and structural connectivity. Cerebral Cortex, 22(1), 232-242. https://doi.org/10.1093/cercor/bhr123

Dustman, R. E., Emmerson, R. Y., \& Shearer, D. E. (1996). Life Span Changes in Electrophysiological Measures of Inhibition. Brain and Cognition, 30(1), 109-126. https://doi.org/10.1006/brcg.1996.0007

Eggenberger, P., Wolf, M., Schumann, M., \& de Bruin, E. D. (2016). Exergame and Balance Training Modulate Prefrontal Brain Activity during Walking and Enhance Executive Function in Older Adults. Frontiers in Aging Neuroscience, 8, 66. https://doi.org/10.3389/fnagi.2016.00066

Eysel, U. T., Shevelev, I. A., Lazareva, N. A., \& Sharaev, G. A. (1998). Orientation tuning and receptive field structure in cat striate neurons during local blockade of intracortical inhibition. Neuroscience, 84(1), 25-36. https://doi.org/10.1016/S0306-4522(97)00378-3

Fernandez, N. B., Hars, M., Trombetti, A., \& Vuilleumier, P. (2019). Age-related changes in attention control and their relationship with gait performance in older adults with high risk of falls. Neurolmage, 189, 551-559. https://doi.org/10.1016/j.neuroimage.2019.01.030

Florence, C. S., Bergen, G., Atherly, A., Burns, E., Stevens, J., \& Drake, C. (2018). The medical costs of fatal falls and fall injuries among older adults. J Am Geriatr Soc, 66(4), 693-698. https://doi.org/10.1111/jgs.15304

Fraser, S. A., Dupuy, O., Pouliot, P., Lesage, F., \& Bherer, L. (2016). Comparable cerebral oxygenation patterns in younger and older adults during dual-task walking with increasing load. Frontiers in Aging Neuroscience, 8, 240. https://doi.org/10.3389/fnagi.2016.00240 
Godde, B., \& Voelcker-Rehage, C. (2010). More automation and less cognitive control of imagined walking movements in high- versus low-fit older adults. Frontiers in Aging Neuroscience, 2(SEP), 1-13. https://doi.org/10.3389/fnagi.2010.00139

Gonzalez-Burgos, L., Hernández-Cabrera, J. A., Westman, E., Barroso, J., \& Ferreira, D. (2019). Cognitive compensatory mechanisms in normal aging: A study on verbal fluency and the contribution of other cognitive functions. Aging, 11(12), 4090-4106. https://doi.org/10.18632/aging.102040

Grady, C. (2012). The cognitive neuroscience of ageing. Nature Reviews Neuroscience, 13(7), 491-505. https://doi.org/10.1038/nrn3256

Grady, C. L., Maisog, J. M., Horwitz, B., Ungerleider, L. G., Mentis, M. J., Salerno, J. A., Pietrini, P., Wagner, E., \& Haxby, J. V. (1994). Age-related changes in cortical blood flow activation during visual processing of faces and location. Journal of Neuroscience, 14(3 II), 1450-1462. https://doi.org/10.1523/jneurosci.14-03-01450.1994

Grady, C. L., Randy McIntosh, A., Horwitz, B., \& Rapoport, S. I. (2000). Age-related changes in the neural correlates of degraded and nondegraded face processing. Cognitive Neuropsychology, 17(1-3), 165-186. https://doi.org/10.1080/026432900380553

Graziano, M. S. A., \& Aflalo, T. N. (2007). Rethinking cortical organization: Moving away from discrete areas arranged in hierarchies. The Neuroscientist, 13(2), 138-147. https://doi.org/10.1177/1073858406295918

Hamacher, D., Herold, F., Wiegel, P., Hamacher, D., \& Schega, L. (2015). Brain activity during walking: A systematic review. Neuroscience and Biobehavioral Reviews, 57, 310-327. https://doi.org/10.1016/j.neubiorev.2015.08.002

Hausdorff, J. M., Rios, D. A., \& Edelberg, H. K. (2001). Gait Variability and Fall Risk in Community-Living Older Adults: A 1-Year Prospective Study. 82, 7. 
Hausman, H. K., Jackson, T. B., Goen, J. R. M., \& Bernard, J. A. (2019). From synchrony to asynchrony: Cerebellar-basal ganglia functional circuits in young and older adults. Cerebral Cortex, 00, 1-12. https://doi.org/10.1093/cercor/bhz121

Hawkins, K. A., Fox, E. J., Daly, J. J., Rose, D. K., Christou, E. A., McGuirk, T. E., Otzel, D. M., Butera, K. A., Chatterjee, S. A., \& Clark, D. J. (2018). Prefrontal over-activation during walking in people with mobility deficits: Interpretation and functional implications. Human Movement Science, 59, 46-55. https://doi.org/10.1016/j.humov.2018.03.010

Hedman, A. M., van Haren, N. E. M., Schnack, H. G., Kahn, R. S., \& Hulshoff Pol, H. E. (2012). Human brain changes across the life span: A review of 56 longitudinal magnetic resonance imaging studies. Human Brain Mapping, 33(8), 1987-2002. https://doi.org/10.1002/hbm.21334

Heinzel, S., Lorenz, R. C., Brockhaus, W.-R., Wustenberg, T., Kathmann, N., Heinz, A., \& Rapp, M. A. (2014). Working memory load-dependent brain response predicts behavioral training gains in older adults. Journal of Neuroscience, 34(4), 1224-1233. https://doi.org/10.1523/jneurosci.2463-13.2014

Heuninckx, S., Wenderoth, N., \& Swinnen, S. P. (2008). Systems neuroplasticity in the aging brain: Recruiting additional neural resources for successful motor performance in elderly persons. The Journal of Neuroscience: The Official Journal of the Society for Neuroscience, 28(1), 91-99. https://doi.org/10.1523/JNEUROSCI.3300-07.2008 Holtzer, R., Kraut, R., Izzetoglu, M., \& Ye, K. (2019). The effect of fear of falling on prefrontal cortex activation and efficiency during walking in older adults. GeroScience, 41(1), 89100. https://doi.org/10.1007/s11357-019-00056-4

Holtzer, R., Mahoney, J. R., Izzetoglu, M., Izzetoglu, K., Onaral, B., \& Verghese, J. (2011). FNIRS study of walking and walking while talking in young and old individuals. Journals of Gerontology - Series A Biological Sciences and Medical Sciences, 66 A(8), 879-887. https://doi.org/10.1093/gerona/glr068 
Holtzer, R., Mahoney, J. R., Izzetoglu, M., Wang, C., England, S., \& Verghese, J. (2015). Online fronto-cortical control of simple and attention-demanding locomotion in humans. Neurolmage, 112, 152-159. https://doi.org/10.1016/j.neuroimage.2015.03.002

Holtzer, R., Verghese, J., Allali, G., Izzetoglu, M., Wang, C., \& Mahoney, J. R. (2016). Neurological gait abnormalities moderate the functional brain signature of the posture first hypothesis. Brain Topography, 29(2), 334-343. https://doi.org/10.1007/s10548-0150465-z

Jahn, K., Deutschländer, A., Stephan, T., Kalla, R., Wiesmann, M., Strupp, M., \& Brandt, T. (2008). Imaging human supraspinal locomotor centers in brainstem and cerebellum. Neurolmage, 39(2), 786-792. https://doi.org/10.1016/j.neuroimage.2007.09.047

Jahn, K., Deutschländer, A., Stephan, T., Strupp, M., Wiesmann, M., \& Brandt, T. (2004). Brain activation patterns during imagined stance and locomotion in functional magnetic resonance imaging. Neurolmage, 22(4), 1722-1731.

https://doi.org/10.1016/j.neuroimage.2004.05.017

Ji, L., Pearlson, G. D., Zhang, X., Steffens, D. C., Ji, X., Guo, H., \& Wang, L. (2018). Physical exercise increases involvement of motor networks as a compensatory mechanism during a cognitively challenging task. International Journal of Geriatric Psychiatry, 33(8), 1153-1159. https://doi.org/10.1002/gps.4909

Jor'dan, A. J., Poole, V. N., Iloputaife, I., Milberg, W., Manor, B., Esterman, M., \& Lipsitz, L. A. (2017). Executive network activation is linked to walking speed in older adults:

Functional MRI and TCD ultrasound evidence from the MOBILIZE Boston Study. The Journals of Gerontology. Series A, Biological Sciences and Medical Sciences, 72(12), 1669-1675. https://doi.org/10.1093/gerona/glx063

Kawagoe, T., Suzuki, M., Nishiguchi, S., Abe, N., Otsuka, Y., Nakai, R., Yamada, M., Yoshikawa, S., \& Sekiyama, K. (2015). Brain activation during visual working memory 
correlates with behavioral mobility performance in older adults. Frontiers in Aging Neuroscience, 7, 186. https://doi.org/10.3389/fnagi.2015.00186

King, B. R., Van Ruitenbeek, P., Leunissen, I., Cuypers, K., Heise, K. F., Santos Monteiro, T., Hermans, L., Levin, O., Albouy, G., Mantini, D., \& Swinnen, S. P. (2018). Age-related declines in motor performance are associated with decreased segregation of large-scale resting state brain networks. Cerebral Cortex, 28(12), 4390-4402. https://doi.org/10.1093/cercor/bhx297

Koen, J. D., \& Rugg, M. D. (2019). Neural Dedifferentiation in the Aging Brain. Trends in Cognitive Sciences, 23(7), 547-559. https://doi.org/10.1016/j.tics.2019.04.012

la Fougère, C., Zwergal, A., Rominger, A., Förster, S., Fesl, G., Dieterich, M., Brandt, T., Strupp, M., Bartenstein, P., \& Jahn, K. (2010). Real versus imagined locomotion: A [18F]-FDG PET-fMRI comparison. Neurolmage, 50(4), 1589-1598. https://doi.org/10.1016/j.neuroimage.2009.12.060

Lanska, D. J., \& Goetz, C. G. (2000). Romberg's sign: Development, adoption, and adaptation in the 19th century. Neurology, 55(8), 1201-1206.

https://doi.org/10.1212/WNL.55.8.1201

Li, K., Bherer, L., Mirelman, A., Maidan, I., \& Hausdorff, J. M. (2018). Cognitive Involvement in Balance, Gait and Dual-Tasking in Aging: A Focused Review From a Neuroscience of Aging Perspective. Frontiers in Neurology, 9, 913.

https://doi.org/10.3389/fneur.2018.00913

Li, K. Z. H., \& Lindenberger, U. (2002). Relations between aging sensory/sensorimotor and cognitive functions. Neuroscience and Biobehavioral Reviews, 26(7), 777-783. https://doi.org/10.1016/S0149-7634(02)00073-8

Li, S. C., Lindenberger, U., \& Sikström, S. (2001). Aging cognition: From neuromodulation to representation. Trends in Cognitive Sciences, 5(11), 479-486. https://doi.org/10.1016/S1364-6613(00)01769-1 
Li, S.-C., \& Lindenberger, U. (1999). Cross-level unification:Computational exploration of the link between deterioration of neurotransmitter and dedifferenciation of cognition in old age. 103-146.

Lindenberger, U., \& Baltes, P. B. (1994). Sensory functioning and intelligence in old age: A strong connection. Psychology and Aging, 9(3), 339-355. https://doi.org/10.1037/08827974.9.3.339

Lövdén, M., Schaefer, S., Pohlmeyer, A. E., \& Lindenberger, U. (2008). Walking variability and working-memory load in aging: A dual-process account relating cognitive control to motor control performance. Journals of Gerontology - Series B Psychological Sciences and Social Sciences, 63(3). https://doi.org/10.1093/geronb/63.3.P121

Madden, D. J., Turkington, T. G., Provenzale, J. M., Denny, L. L., Hawk, T. C., Gottlob, L. R., \& Coleman, R. E. (1999). Adult age differences in the functional neuroanatomy of verbal recognition memory. Human Brain Mapping, 7(2), 115-135. https://doi.org/10.1002/(SICI)1097-0193(1999)7:2<115::AID-HBM5>3.0.CO;2-N

Marx, E., Stephan, T., Nolte, A., Deutschländer, A., Seelos, K. C., Dieterich, M., \& Brandt, T. (2003). Eye closure in darkness animates sensory systems. Neurolmage, 19(3), 924934. https://doi.org/10.1016/S1053-8119(03)00150-2

Mattay, V. S., Fera, F., Tessitore, A., Hariri, A. R., Das, S., Callicott, J. H., \& Weinberger, D. R. (2002). Neurophysiological correlates of age-related changes in human motor function. Neurology, 58(4), 630-635. https://doi.org/10.1212/WNL.58.4.630

Mattay, Venkata. S., Fera, F., Tessitore, A., Hariri, A. R., Berman, K. F., Das, S., MeyerLindenberg, A., Goldberg, T. E., Callicott, J. H., \& Weinberger, D. R. (2006). Neurophysiological correlates of age-related changes in working memory capacity. Neuroscience Letters, 392(1-2), 32-37. https://doi.org/10.1016/j.neulet.2005.09.025 
Melie-Garcia, L., Slater, D., Ruef, A., Sanabria-Diaz, G., Preisig, M., Kherif, F., Draganski, B., \& Lutti, A. (2018). Networks of myelin covariance. Human Brain Mapping, 39(4), 15321554. https://doi.org/10.1002/hbm.23929

Meunier, D., Stamatakis, E. A., \& Tyler, L. K. (2014). Age-related functional reorganization, structural changes, and preserved cognition. Neurobiology of Aging, 35(1), 42-54. https://doi.org/10.1016/j.neurobiolaging.2013.07.003

Mirelman, A., Maidan, I., Bernad-Elazari, H., Shustack, S., Giladi, N., \& Hausdorff, J. M. (2017). Effects of aging on prefrontal brain activation during challenging walking conditions. Brain and Cognition, 115, 41-46. https://doi.org/10.1016/j.bandc.2017.04.002

Mitchell, T., Starrs, F., Soucy, J.-P., Thiel, A., \& Paquette, C. (2019). Impaired sensorimotor processing during complex gait precedes behavioral changes in middle-aged adults. The Journals of Gerontology. Series A, Biological Sciences and Medical Sciences, 74(12), 1861-1869. https://doi.org/10.1093/gerona/gly210

Nishiguchi, S., Yamada, M., Tanigawa, T., Sekiyama, K., Kawagoe, T., Suzuki, M., Yoshikawa, S., Abe, N., Otsuka, Y., Nakai, R., Aoyama, T., \& Tsuboyama, T. (2015). A 12-week physical and cognitive exercise program can improve cognitive function and neural efficiency in community-dwelling older adults: A randomized controlled trial. Journal of the American Geriatrics Society, 63(7), 1355-1363. https://doi.org/10.1111/jgs.13481

Noohi, F., Kinnaird, C., De Dios, Y., Kofman, I., Wood, S. J., Bloomberg, J. J., Mulavara, A. P., Sienko, K. H., Polk, T. A., \& Seidler, R. D. (2019). Deactivation of somatosensory and visual cortices during vestibular stimulation is associated with older age and poorer balance. PLOS ONE, 14(9), e0221954. https://doi.org/10.1371/journal.pone.0221954

Osofundiya, O., Benden, M. E., Dowdy, D., \& Mehta, R. K. (2016). Obesity-specific neural cost of maintaining gait performance under complex conditions in community-dwelling older adults. Clinical Biomechanics (Bristol, Avon), 35, 42-48.

https://doi.org/10.1016/j.clinbiomech.2016.03.011 
Peterka, R. J. (2002). Sensorimotor Integration in Human Postural Control. Journal of Neurophysiology, 88(3), 1097-1118. https://doi.org/10.1152/jn.2002.88.3.1097

Reuter-Lorenz, P. A., \& Cappell, K. A. (2008). Neurocognitive aging and the compensation hypothesis. Current Directions in Psychological Science, 17(3), 177-182. https://doi.org/10.1111/j.1467-8721.2008.00570.x

Reuter-Lorenz, P. A., Jonides, J., Smith, E. E., Hartley, A., Miller, A., Marshuetz, C., \& Koeppe, R. A. (2000). Age differences in the frontal lateralization of verbal and spatial working memory revealed by PET. Journal of Cognitive Neuroscience, 12(1), 174-187. https://doi.org/10.1162/089892900561814

Reuter-Lorenz, P. A., Stanczak, L., \& Miller, A. C. (1999). Neural Recruitment and Cognitive Aging: Two Hemispheres Are Better Than One, Especially as You Age. Psychological Science, 10(6), 494-500. https://doi.org/10.1111/1467-9280.00195

Sakurai, R., Fujiwara, Y., Yasunaga, M., Takeuchi, R., Murayama, Y., Ohba, H., Sakuma, N., Suzuki, H., Oda, K., Sakata, M., Toyohara, J., Ishiwata, K., Shinkai, S., \& Ishii, K. (2014). Regional cerebral glucose metabolism and gait speed in healthy community-dwelling older women. The Journals of Gerontology. Series A, Biological Sciences and Medical Sciences, 69(12), 1519-1527. https://doi.org/10.1093/gerona/glu093

Sakurai, R., Ishii, K., Yasunaga, M., Takeuchi, R., Murayama, Y., Sakuma, N., Sakata, M., Oda, K., Ishibashi, K., Ishiwata, K., Fujiwara, Y., \& Montero-Odasso, M. (2017). The neural substrate of gait and executive function relationship in elderly women: A PET study. Geriatrics \& Gerontology International, 17(11), 1873-1880. https://doi.org/10.1111/ggi.12982

Sato, H., Katsuyama, N., Tamura, H., Hata, Y., \& Tsumoto, T. (1996). Mechanisms underlying orientation selectivity of neurons in the primary visual cortex of the macaque. The Journal of Physiology, 494(3), 757-771. https://doi.org/10.1113/jphysiol.1996.sp021530 
Schättin, A., Arner, R., Gennaro, F., \& de Bruin, E. D. (2016). Adaptations of Prefrontal Brain Activity, Executive Functions, and Gait in Healthy Elderly Following Exergame and Balance Training: A Randomized-Controlled Study. Frontiers in Aging Neuroscience, 8, 278. https://doi.org/10.3389/fnagi.2016.00278

Schmolesky, M. T., Wang, Y., Pu, M., \& Leventhal, A. G. (2000). Degradation of stimulus selectivity of visual cortical cells in senescent rhesus monkeys. Nature Neuroscience, 3(4), 384-390. https://doi.org/10.1038/73957

Schneider-Garces, N. J., Gordon, B. A., Brumback-Peltz, C. R., Shin, E., Lee, Y., Sutton, B. P., Maclin, E. L., Gratton, G., \& Fabiani, M. (2010). Span, CRUNCH, and beyond: Working memory capacity and the aging brain. Journal of Cognitive Neuroscience, 22(4), 655669. https://doi.org/10.1162/jocn.2009.21230

Schulz, B. W. (2012). Healthy younger and older adults control foot placement to avoid small obstacles during gait primarily by modulating step width. Journal of NeuroEngineering and Rehabilitation, 9(1), 69. https://doi.org/10.1186/1743-0003-9-69

Seidler, R. D., Bernard, J. A., Burutolu, T. B., Fling, B. W., Gordon, M. T., Gwin, J. T., Kwak, Y., \& Lipps, D. B. (2010). Motor control and aging: Links to age-related brain structural, functional, and biochemical effects. Neuroscience and Biobehavioral Reviews, 34(5), 721-733. https://doi.org/10.1016/j.neubiorev.2009.10.005

Shimada, H., Ishii, K., Ishiwata, K., Oda, K., Suzukawa, M., Makizako, H., Doi, T., \& Suzuki, T. (2013). Gait adaptability and brain activity during unaccustomed treadmill walking in healthy elderly females. Gait \& Posture, 38(2), 203-208. https://doi.org/10.1016/j.gaitpost.2012.11.008

Shumway-Cook, A., Patla, A. E., Stewart, A., Ferrucci, L., Ciol, M. A., \& Guralnik, J. M. (2002). Environmental Demands Associated With Community Mobility in Older Adults With and Without Mobility Disabilities. Physical Therapy, 82(7), 670-681. https://doi.org/10.1093/ptj/82.7.670 
Spedden, M. E., Choi, J. T., Nielsen, J. B., \& Geertsen, S. S. (2019). Corticospinal control of normal and visually guided gait in healthy older and younger adults. Neurobiology of Aging, 78, 29-41. https://doi.org/10.1016/j.neurobiolaging.2019.02.005

Stuart, S., Alcock, L., Rochester, L., Vitorio, R., \& Pantall, A. (2019). Monitoring multiple cortical regions during walking in young and older adults: Dual-task response and comparison challenges. International Journal of Psychophysiology: Official Journal of the International Organization of Psychophysiology, 135, 63-72. https://doi.org/10.1016/j.jpsycho.2018.11.006

Vitorio, R., Stuart, S., Gobbi, L. T. B., Rochester, L., Alcock, L., \& Pantall, A. (2018). Reduced Gait Variability and Enhanced Brain Activity in Older Adults With Auditory Cues: A Functional Near-Infrared Spectroscopy Study. Neurorehabilitation and Neural Repair, 32(11), 976-987. https://doi.org/10.1177/1545968318805159

Voss, M. W., Prakash, R. S., Erickson, K. I., Basak, C., Chaddock, L., Kim, J. S., Alves, H., Heo, S., Szabo, A. N., White, S. M., Wójcicki, T. R., Mailey, E. L., Gothe, N., Olson, E. A., McAuley, E., \& Kramer, A. F. (2010). Plasticity of brain networks in a randomized intervention trial of exercise training in older adults. Frontiers in Aging Neuroscience, 2. https://doi.org/10.3389/fnagi.2010.00032

Wagshul, M. E., Lucas, M., Ye, K., Izzetoglu, M., \& Holtzer, R. (2019). Multi-modal neuroimaging of dual-task walking: Structural MRI and fNIRS analysis reveals prefrontal grey matter volume moderation of brain activation in older adults. Neurolmage, 189, 745-754. https://doi.org/10.1016/j.neuroimage.2019.01.045

Wai, Y.-Y., Wang, J.-J., Weng, Y.-H., Lin, W.-Y., Ma, H.-K., Ng, S.-H., Wan, Y.-L., \& Wang, C.H. (2012). Cortical involvement in a gait-related imagery task: Comparison between Parkinson's disease and normal aging. Parkinsonism \& Related Disorders, 18(5), 537542. 
Ward, N. S., \& Frackowiak, R. S. J. (2013). Age-related changes in the neural correlates of motor performance. Brain, 126(0 4), 873-888. https://doi.org/10.1093/brain/awg071 